\title{
Potential Ecological Risk and Human Health Risk Assessment of Heavy Metal Pollution in Industrial Affected Soils by Coal Mining and Metallurgy in Ostrava, Czech Republic
}

\author{
Helena Doležalová Weissmannová ${ }^{1, *}$ (D) Silvie Mihočová ${ }^{1}$, Petr Chovanec ${ }^{1}$ and Jiří Pavlovský ${ }^{2}$ \\ 1 Faculty of Chemistry, Brno University of Technology, Purkyňova 118, 61200 Brno, Czech Republic; \\ mihocova@fch.vutbr.cz (S.M.); chovanec1987@gmail.com (P.C.) \\ 2 Department of Chemistry, Faculty of Materials Science and Technology, VŠB-Technical University of \\ Ostrava, 17. listopadu 2172/15, 70800 Ostrava-Poruba, Czech Republic; jiri.pavlovsky@vsb.cz \\ * Correspondence: dolezalova@fch.vutbr.cz
}

Received: 9 October 2019; Accepted: 11 November 2019; Published: 14 November 2019

\begin{abstract}
The heavy metal pollution of soils has become serious environmental problem, mainly in localities with high industrialization and rapid growth. The purpose of this detailed research was to determine the actual status of heavy metal pollution of soils and an assessment of heavy metal pollution in a highly industrialized city, Ostrava, with a history of long-term impacts from the metallurgy industry and mining. The ecological risks to the area was subsequently also assessed. The heavy metals $\mathrm{Cd}, \mathrm{Hg}, \mathrm{Cu}, \mathrm{Mn}, \mathrm{Pb}, \mathrm{V}, \mathrm{Zn}, \mathrm{Cr}$ and Fe were determined in top-soils $(0-20 \mathrm{~cm})$ using atomic absorption spectrometry (F AAS, GF AAS) from three areas with different anthropogenic loads. The obtained data expressed as mean metal concentrations were very varied among the sampled soils and values of all analyzed metal concentrations were higher than its background levels. To identify the ecological risk and assessment of soil pollution, various pollution indices were calculated, such as single pollution indices ( $\mathrm{I}_{\text {geo }}, \mathrm{CF}, \mathrm{EF}, \mathrm{PI}$ ) and total complex indices (IPI, PLI, $\mathrm{PI}_{\text {Nemerow }}, \mathrm{C}_{\mathrm{deg}}, \mathrm{mC}_{\mathrm{deg}}$, $\mathrm{E}_{\mathrm{r}}$ and PERI). The identification of pollution sources was assessed using Pearson's correlation analysis and multivariate methods (HCA, PCA/FA). The obtained results confirmed three major groups of metals $(\mathrm{Fe}-\mathrm{Cr}, \mathrm{Pb}-\mathrm{Cu}$ and $\mathrm{Mn}-\mathrm{V})$. A human health risk was identified in the case of $\mathrm{Pb}, \mathrm{Cd}$ and $\mathrm{Cr}$, and the $\mathrm{HI}$ value of $\mathrm{V}$ for children also exceeded 1 .
\end{abstract}

Keywords: heavy metals; soils; pollution assessment; ecological risk; human health risk

\section{Introduction}

Metal-polluted soils have become a global and major environmental problem in many parts of the world. Many research studies are focused on monitoring heavy metal concentrations in soils, such as $\mathrm{Cu}, \mathrm{Zn}, \mathrm{Fe}, \mathrm{Mn}, \mathrm{Co}, \mathrm{Ni}, \mathrm{Pb}, \mathrm{Cd}, \mathrm{Cr}, \mathrm{As}$ and $\mathrm{Hg}$, which very often have been extensively studied, mainly in urban, agricultural and industrial affected soils [1-6]. The pollution of soils together with water and wind erosion, soil degradation, loss of organic matter, disruption of water cycles and acidification processes have adversely impacted soil functions. Heavy metals originating from anthropogenic activities are among the most common and oldest environmental contaminants. The occurrence of heavy metals and some semi-metals in the environment (soil, water and air) increases the potential intake of these usually toxic substances by the living organisms but also accumulate in various body organs (kidney, liver and bone) and cause damage to body systems (nervous, skeletal, endocrine and immune, circulatory, etc.) [7-9]. The high soil pollution by heavy metals results in enormous potential ecological risks in threatened areas with typical rapid urbanization, industrialization and 
agricultural development. These global pollution trends state serious problems to human health and disrupt the balance of local ecosystems. Heavy metal pollution is hidden, permanent and irreversible due to the basic character of heavy metals, such as accumulation, persistence and low mobility in soils. Growing industrial development, waste production and agricultural emissions of heavy metals have major roles in the rapid increase of metal pollution in soils; anthropogenic activity is therefore the reason for the rapidly growing pollution trend [10-13]. Mining and metallurgical activities also affect the presence of other elements in soil, in particular As, Cd and Zn. High levels of metals and pronounced soil contamination can be detectable at a distance nearly $1.5 \mathrm{~km}$ from the source $[4,6,14-18]$. Intensive mining industry caused severe pollution in some areas in the past decades in the Czech Republic, mainly Ostrava. During long periods, an enormous amount of mining, processing and metallurgical waste were produced. General problems in these areas were slow, insufficient or missing remediation processes. Currently, the Ostrava region is the only locality with mining of black coal in Czech Republic. During the period 1990-2001, numerous coal mines were closed and only three coal mines are still operated. This fact led to a change in the usage of high-quality black coal and its substitution with cheaper and lower quality brown coal, mainly used in many household heating systems in the Ostrava region.

The main objectives of this study are (1) determination of total concentrations of $\mathrm{Cd}, \mathrm{Hg}, \mathrm{Cu}$, $\mathrm{Mn}, \mathrm{Pb}, \mathrm{V}, \mathrm{Zn}, \mathrm{Cr}$ and $\mathrm{Fe}$ and pollution degrees in soils in relation to industrial activities in Ostrava; (2) application and calculation of single and total complex indices for pollution assessment of soils and assessment of environmental risk in this area; (3) identification of pollution sources of heavy metals in soils from Ostrava based on multivariate statistical method; (4) identification of ecological risk in Ostrava; and (5) evaluation of carcinogenic and non-carcinogenic risk in Ostrava, as well as health risk assessment.

\section{Materials and Methods}

\subsection{Study Area and Sample Collection}

The Ostrava region is located in the Moravia-Silesian Region in north-eastern Czech Republic, near the border with Poland, and lies in the center of the Ostrava Basin that is a geomorphological unit in North Moravia and Silesia. This region is one of the most industrialized and urbanized sites in Central Europe and the characteristic long-term problems in this region are enormous air pollution due to anthropogenic activity and many pollution sources, which are some of the highest in Europe. The Ostrava agglomeration is densely populated $\left(978 / \mathrm{km}^{2}\right)$ and with area $331.53 \mathrm{~km}^{2}$. The rapid economic and urbanization trend were in the last century due to fast development of coal production, steel and heavy industries (steelworks, metallurgical industry, production of steel alloys, metalworking, etc.). A high-concentration industry, large density of local coal combustion due to local heating needs and a very high infrastructure for mainly transport, all belong among the highest pollution sources in this region. Many localities in this area are therefore seriously and long-term affected. Pollution of air, soil and water (emissions) is the most serious problem in Ostrava.

The main part of Ostrava is characterized by industry with high emissions and typical there is enormous metallurgical production that is not similar in the Czech Republic. The quality of soil, air water, indeed the whole environment, is strongly affected by high dense transport, local coal combustion, non-maintained areas and the effects of mining and other anthropogenic activities. The high and usually occurring smog situation is typical for the Ostrava agglomeration (Figure 1) and the amount of particular matter ( $\left.\mathrm{PM}_{10}\right)$, hydrocarbons (mainly benzo(a)pyrene), heavy metals $(\mathrm{Pb}, \mathrm{Cd}, \mathrm{Cr}, \mathrm{Hg}$, etc.), as well as oxides of sulfur and nitrogen are often exceeded. Additionally, several stationary industrial sources of pollutants (e.g., metals, particulate matter, nitrogen oxides, sulfur dioxide, and benzo(a)pyrene) exist directly in the city or in the surroundings. 


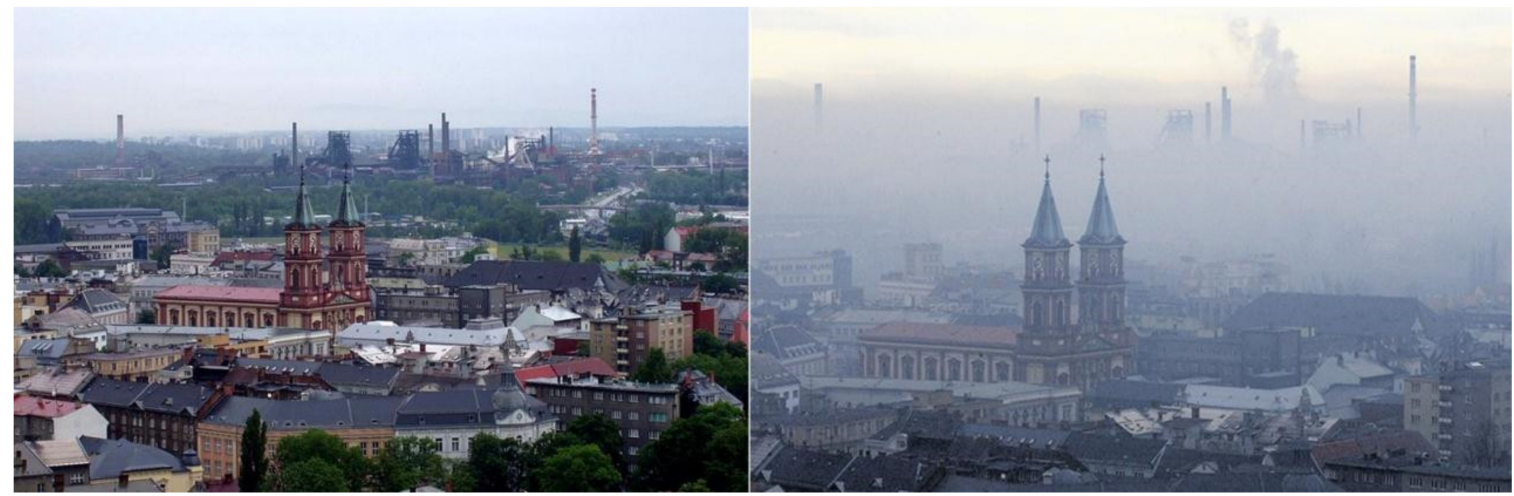

Figure 1. A typical smog situation in Ostrava-view of the center of Ostrava and Vítkovice (the metallurgy and steel machinery group) in various smog situations.

Parallel sampling series were carried out at 29 sites and from a depth of $20 \mathrm{~cm}$ depending on the distance from the major pollution source and soil samples were collected in accordance with ISO 11465 (1993), ISO 10381-5 (2005) and ISO 10390 (2005). All sampling sites were identified by a GPS system (TOMTOM) and sites are shown in Figure 2. Soil samples were transferred in polyethylene zipper bags preventing sample oxidation to the laboratory for chemical analysis [19-22].

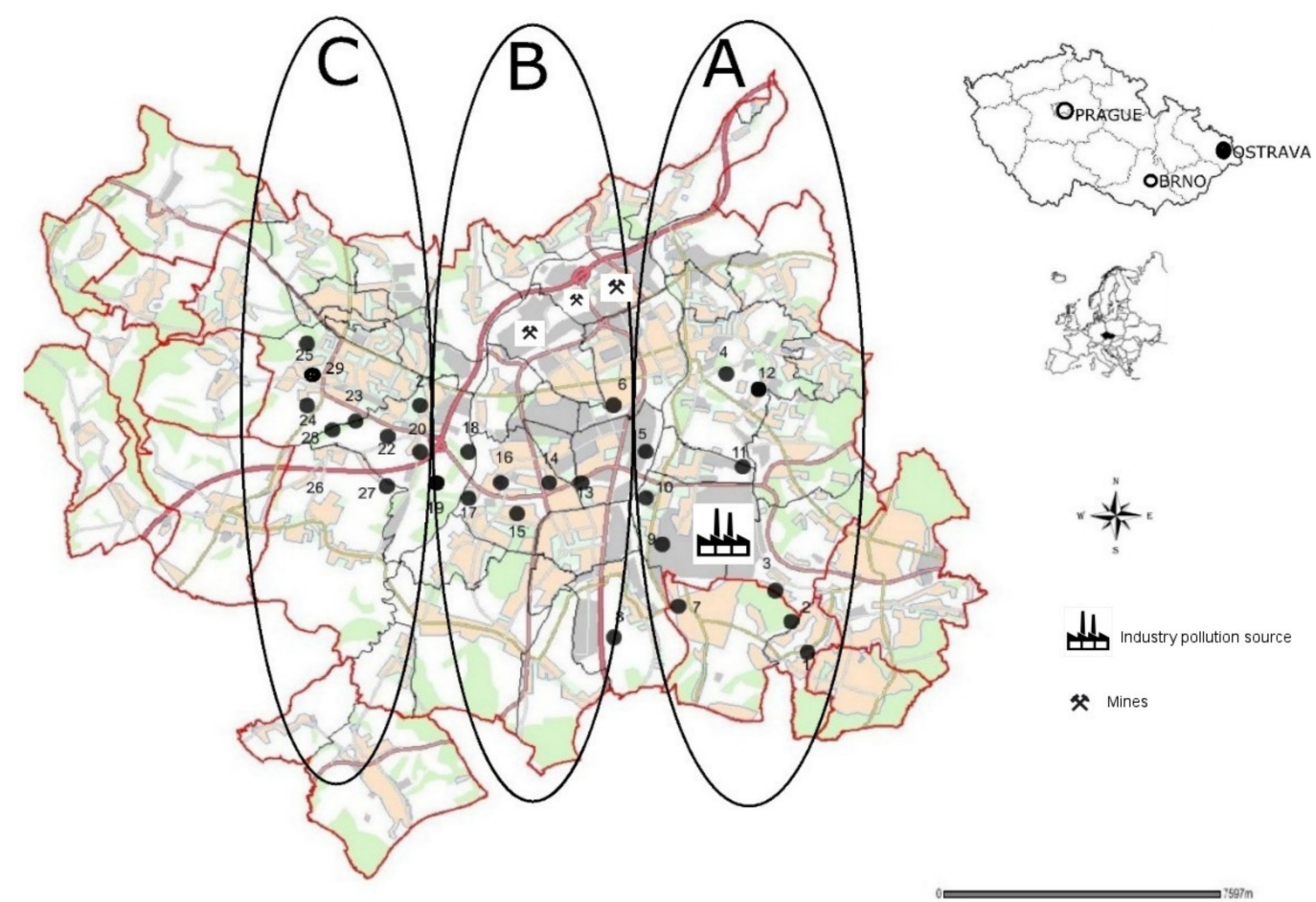

Figure 2. Location of the study area and sampling site in Ostrava (created from MAP 2019 [23]), modified and added onto the sampling points and sites $\mathbf{A}, \mathbf{B}$ and $\mathbf{C}$.

The soil samples were classified into 3 groups depending on the pollution source distance (A: $0-5 \mathrm{~km}, \mathrm{~B}: 5-10 \mathrm{~km}$ and C: $10-16 \mathrm{~km}$ ) and type of land utility. The samples from Site A were characterized as industry affected soils; Site B as urban land; and Site C as suburban with high traffic loads.

\subsection{Chemical Analysis}

The samples were air-dried at laboratory temperature $\left(22 \pm 2{ }^{\circ} \mathrm{C}\right)$ until constant weight and afterwards sieved through a $2 \mathrm{~mm}$ sieve, firstly, and again sieved through a $150 \mu \mathrm{m}$ nylon sieve. 
The dry matter of soil samples ( $1 \mathrm{~g}$ ) was determined by the gravimetric method (ISO 11465-1993). Measurements of $\mathrm{pH}$ were determined electrochemically using the WTW $\mathrm{pH} 320$ system in accordance of method ISO 10390-2005. The air-dried soil samples $(0.5000 \pm 0.001 \mathrm{~g})$ were digested with concentrated $\mathrm{HNO}_{3}\left(2 \mathrm{~mol} \mathrm{~L}-1\right.$, p.a. purity, Merck \& Co., Inc.) and continuously shaken $\left(16 \mathrm{~h}\right.$, at $\left.22 \pm 1{ }^{\circ} \mathrm{C}\right)$. Soil acid suspensions were filtered through a $0.45 \mu \mathrm{m}$ membrane filter. The glassware were cleaned in $\mathrm{HNO}_{3}(10 \%)$ by soaking for at least $24 \mathrm{~h}$ and washed in deionized water. Milli-Q water (resistivity over $18 \mathrm{M} \Omega / \mathrm{cm}$ ) was used for preparing soil extraction solutions, as well as standards and blank solutions. The total concentration of $\mathrm{Cd}$ and $\mathrm{V}$ were determined by graphite furnace atomic absorption spectrometry (GF AAS; ZEEnit model AAS 60-Analytical Jena). The total concentrations of Pb, Zn, $\mathrm{Cu}$ and $\mathrm{Mn}$ were determined by flame atomic absorption spectrometry (FAAS; SpectrAA 30, Varian). The residual mercury content in the solid soil samples and extraction solutions were determined by a mercury analyzer AMA 254 (Advanced Mercury Analyzer).

The certified reference materials (QCM) METRANAL 34 and certified standard solution of CRM ASTASOL were used for QA/QC. The quality control checks were performed using reagent blanks, triplicate samples and certified quality control materials (QCM) METRANAL 34. The quality control materials METRANAL 34 was used to verify the accuracy of the analytical procedures The check standard of mercury was prepared by mixing $0.5 \mathrm{~mL}$ concentrated $\mathrm{HNO}_{3}$ and $0.5 \mathrm{~mL}$ concentrated $\mathrm{HCl}$ and $0.5 \mathrm{~mL} \mathrm{~K}_{2} \mathrm{Cr}_{2} \mathrm{O}_{7}(1 \%)$ solution and adding $10 \mu \mathrm{L}$ of the standard mercury solution (ANS024, $\left.1 \mathrm{~g} \mathrm{~L}^{-1}\right)$ in $50 \mathrm{~mL}$. The quality control of soil analysis was performed using a certified standard solution of CRM ASTASOL-Cd (ANS010), V (ANS065), Pb(ANS041), Zn (ANS069), Cu (ANS015), Mn (ANS033), $\mathrm{Cr}$ (ANS033), Hg (ANS024) from ANALYTIKA ${ }^{\circledR}$, spol. s r.o., CZ. The matrix composition of METRANAL 34 is presented in Table S1 (Supplementary Materials). Each sample was analyzed in triplicate and RSD (relative standard deviation) varied from 3\% to 10\%. The standard errors for the measurements in the soil samples were in the range $0.1-0.5 \%$. The limit of detection (LOD) and limit of quantification (LOQ) were also determined LOD- $\mathrm{Pb} 0.95, \mathrm{Cd} 4.09 .10^{-4}, \mathrm{Cu} 0.25, \mathrm{Cr} 0.09$, Fe 2.51, Mn 0.20, V 9.15.10-3, Zn 0.26 and LOQ Pb 3.17, Cd 1.37.10-3, Cu 0.95, Cr 1.08, Fe 3.26, Mn 0.67, V 3.05.10-2 and Zn $0.87 \mathrm{mg} \mathrm{L}^{-1}$. The experimentally obtained data were calculated on the dry weight and were expressed as means.

\subsection{Pollution and Ecological Risk Assessment}

Single and total complex indices were used for assessment of soil pollution by heavy metals in Ostrava (A—industrialized sites; B — sites with high urban density and traffic; and C—-the peripheral part of Ostrava). The calculation methods (equations) of single and total complex indices used in this study are summarized, calculated and mentioned in many scientific articles, almost over several hundred articles, which are presented in (Table S2, Supplementary Materials) [6,24-26]. The pollution indices present the most effective tools of heavy metal pollution assessment in soils in comparison to total metal concentration in soils. The single indices calculated in this study allowed assessing the soil pollution with individual heavy metals and also calculated for each metal on the base their total concentration in soils and its contents, geochemical background or preindustrial levels. The geoaccumulation index ( $\mathrm{I}_{\text {geo }}$ ) allows assessment of heavy soil metal contamination on the base metal concentrations in the soil sample (topsoils) and the geochemical background of the metal as the reference level. The enrichment factor (EF) allows assessment of the degree of intensity of anthropogenic activities; the reference background concentrations of $\mathrm{Fe}, \mathrm{Al}, \mathrm{Ca}, \mathrm{Ti}, \mathrm{Sc}$ or $\mathrm{Mn}$ are often used for calculation and identify anthropogenic impact of heavy metal concentrations in the soil. The contamination factor (CF) is used for assessment of soil pollution in relation to heavy metal concentration in soils and pre-industrial reference levels, and allows to identify the heavy metal pollution impact of soil due to anthropogenic activities $[27,28]$. The total complex indices presented in this study include the integrated pollution index (IPI), integrated threshold pollution index $\left(\mathrm{IPI}_{\mathrm{T}}\right)$, pollution load index $(\mathrm{PLI})$, degree of contamination $\left(\mathrm{C}_{\mathrm{deg}}\right)$, modified contamination factor $\left(\mathrm{mC}_{\mathrm{deg}}\right)$ and 
Nemerow pollution index $\left(\mathrm{PI}_{\text {Nemerow }}\right)$, and these indices are calculated on the basis of single indices and serve to assess the degree of contamination in a soil environment $[29,30]$.

The integrated pollution index (IPI) is expressed as the mean value of single pollution indices of the metal (PI) that is calculated as the ratio mean of metal concentration in the soil and the geochemical background of individual metals. The integrated threshold pollution index $\left(\mathrm{IPI}_{\mathrm{T}}\right)$ is also called multielement contamination and can identify the soil pollution with regard to tolerable limits (national guidance permissible limits) of individual metals and also assess the common effect of metals in soil [31]. The pollution load index (PLI) serve to identify the accumulation levels of heavy metal contamination in soils and is calculated on the basis of the contamination factors (CF) of individual metals. The PLI provides a simple and comparative mean for assessment of quality in a site [32,33]. The degree of contamination $\left(\mathrm{C}_{\mathrm{deg}}\right)$ and modified contamination factor $\left(\mathrm{mC}_{\mathrm{deg}}\right)$ are used for assessment of metal pollution status or level in soils. The Nemerow Pollution Index ( $\mathrm{PI}_{\text {Nemerow }}$ ) evaluates the total soil pollution degree with respect to contents of all determined heavy metals and their geochemical background and assesses the quality of soils. Ecological risk assessment is expressed as the potential ecological risk index (PERI, or RI), and combine the single index of ecological risk factor $\left(\mathrm{E}_{\mathrm{r}}^{\mathrm{i}}\right)$ and the toxic response factor of individual metal $T_{r}^{i}$, whereas PERI (RI) is expressed as the sum of potential risks of individual metals $\mathrm{E}_{\mathrm{r}}^{\mathrm{i}}$ that is calculated multiplying the toxic-response factor of metal $T_{r}^{i}$ by contamination factor (CF). The toxic response factor $T_{r}^{i}$ is defined as 40, 30, 10, 5, 5, 5, 2, 2, 1, 1 and 1 for $\mathrm{Hg}, \mathrm{Cd}, \mathrm{As}, \mathrm{Cu}, \mathrm{Pb} \mathrm{Ni}, \mathrm{Cr}, \mathrm{V}, \mathrm{Zn}, \mathrm{Mn}$ and Ti. [27,34-42].

\subsection{Health Risk Assessment}

Health risk assessments of heavy metals in soils are widely used to allow quantification of carcinogenic and non-carcinogenic risks to humans via ingestion, inhalation, dermal and dietary exposure pathways. The basic equation for human exposure and evaluation of health risk assessment, including the carcinogenic and non-carcinogenic risks of heavy metals, are the based on the recommendations and methodology of United States Environmental Protection Agency (1989) (USEPA 2001) [43-48].

The chronic daily intake (CDI; $\mathrm{mg} / \mathrm{kg} /$ day) of heavy metals via ingestion $\left(C D I_{\text {Ing }}\right)$, dermal contact $\left(C D I_{\text {Derm }}\right)$ and inhalation $\left(C D I_{I n h}\right)$ for children and adults were calculated by formulas

$$
\begin{gathered}
C D I_{\text {Ing }}=\frac{C_{\text {soil }} \cdot R_{\text {Ing }} \cdot E F \cdot E D}{B W \cdot A T} \cdot 10^{-6}, \\
C D I_{\text {Derm }}=\frac{C_{\text {soil }} \cdot S A \cdot A F \cdot A B S \cdot E F \cdot E D}{B W \cdot A T} \cdot 10^{-6}, \\
C D I_{\text {Inh }}=\frac{C_{\text {soil }} \cdot E F \cdot E T \cdot E D}{P E F \cdot B W \cdot A T},
\end{gathered}
$$

where $C_{\text {soil }}$ is the concentration in soil (mg/kg), $R$ is the rate of ingestion $(100 \mathrm{mg} /$ day (adult), $200 \mathrm{mg} /$ day (children)), $E F$ is the exposure frequency $(350 \mathrm{~d} / \mathrm{a}), E D$ is the exposure duration (24 years (adult), 6 years (children)), ET is the exposure duration $(24 \mathrm{~h} / \mathrm{d}), B W$ is the body weight of the exposed individual $(70 \mathrm{~kg}$ (adult), $15 \mathrm{~kg}$ (children)), $A T$ is the averaging time (days), $365 \times E D$ adult/children, $S A$ is the exposed skin area $\left(5700 \mathrm{~cm}^{2}\right)$; $A F$-adherence factor: $0.07 \mathrm{mg} \cdot \mathrm{cm}^{-2}, A B S$ is the dermal absorption fraction: 0.03 (As), 0.001 (other metals), and PEF is the particle emission factor: $1.36 \times 10^{9} \mathrm{~m}^{3} \mathrm{~kg}^{-1}$ [49-52].

The hazard index $(H I)$ indicates the cumulative non-carcinogenic risk. The $H I$ is equal to the sum of the hazard quotient $(H Q)$ that express non-carcinogenic risk from individual heavy metals, and $H Q$ is calculated according the equations

$$
\begin{aligned}
& H Q=\frac{C D I}{R f D}, \\
& H I=\sum H Q,
\end{aligned}
$$


where RfD is the chronic reference dose of the toxicant $\left(\mathrm{mg} \mathrm{kg}^{-1} \mathrm{~d}^{-1}\right)$ and are different for each element of heavy metal $(\mathrm{Cu}-0.0371, \mathrm{Co}-0.02, \mathrm{Fe}-0.7, \mathrm{~Pb}-0.0035, \mathrm{Zn}-0.3, \mathrm{Cr}-0.003, \mathrm{Cd}-0.001, \mathrm{Ni}-0.0008$ and $\mathrm{As}-0.0003)$. The metals such as $\mathrm{As}, \mathrm{Cd}, \mathrm{Cr}$ and $\mathrm{Pb}$ are classified into metals with carcinogenic risk, and $\mathrm{Fe}, \mathrm{Zn}, \mathrm{Cu}, \mathrm{Ni}$ and $\mathrm{Co}$ are non-carcinogenic.

If the $H I$ is $<1$, no risks from non-carcinogenic effects probably occurred, and if the $H I$ is $>1$, adverse health effects are possible, and the probability of effects increases with the increases in the $H I$ values. The value of carcinogenic risk $(C R)$ can be expressed as

$$
\begin{aligned}
& C R=C D I_{x} \cdot S F, \\
& L C R=\sum C R,
\end{aligned}
$$

where $S F$ is the carcinogenicity slope factor, and values for $\mathrm{Cd}, \mathrm{Cr}, \mathrm{Pb}$ and As are 6.3, 0.5, 0.0085 and $1.5 \mathrm{mg} / \mathrm{kg} / \mathrm{day}$. If $C R<10^{-6}$ the carcinogenic risks to human health from the soil can be considered as negligible, the range $1.10^{-6}-1 \cdot 10^{-4}$ could be considered as posing an acceptable risk to humans and if $C R>10^{-4}$ presents a high risk for the development of cancer in humans. The sum of $C R$ represents total cancer risk over lifetime $L C R$. The acceptable threshold value of $C R$ is $1.0 .10^{-4}$ and the range of tolerable value $L C R$ is from $1.0 \cdot 10^{-6}$ to $1.0 .10^{-4}$ [49-54].

\subsection{Data Analysis}

The statistical analysis was carried out using descriptive statistics and multivariate statistical techniques-hierarchical cluster analysis (HCA) and principal component analysis (PCA) with factor analysis (FA). The multivariate statistical methods (HCA, PCA/FA) are often used in environmental research of pollution assessment of soils. These statistical methods play a main role in the effective evaluating of objects in the system and is categorized based on their similarities and properties $[25,28,29,55-57]$. Descriptive statistics and multivariate statistical methods (HCA, PCA) were performed using software STATISTICA ${ }^{\circledR}$ software (version 12.5) and Microsoft Excel ${ }^{\circledR}$ (2013).

\section{Results and Discussion}

\subsection{The Total Concentration of Heavy Metals in Soils}

The total concentrations of heavy metals in soils $(\mathrm{Cd}, \mathrm{Hg}, \mathrm{Cu}, \mathrm{Mn}, \mathrm{Pb}, \mathrm{V}, \mathrm{Zn}, \mathrm{Cr}$ and $\mathrm{Fe}$ ) from Ostrava and samples from district sites A, B and C, and the descriptive statistical analysis of heavy metals in the soil, are summarized in Table 1 . The entering of heavy metals includes different emission sources of soil pollution by heavy metals, mainly traffic, industry emissions, local combustion of coal and municipal wastes. The extensive emissions of industrial dusts containing heavy metals originate from steel production processes and are the most important. The soils were divided in three classes (A: 1-10, B: 11-19 and C: 20-29) depending on pollution source distance (0-5 km, 5-10 km and 10-16 km). The total amount followed in order $\mathrm{Hg}<\mathrm{Cd}<\mathrm{Fe}<\mathrm{Cr}<\mathrm{Cu}<\mathrm{Pb}<\mathrm{V}<\mathrm{Zn}<\mathrm{Mn}$.

The total metal concentration varied for $\mathrm{Hg}, 0.08-1.31$ mg.kg ${ }^{-1}$ (median $0.19 \pm 0.02$ ), $\mathrm{Pb}$, 11.09-174.03 mg.kg-1 (median 37.71 \pm 3.04 ), Cd, $0.05-1.18$ mg.kg ${ }^{-1}$ (median $\left.0.21 \pm 0.02\right), \mathrm{Cu}, 4.88-98.83$ mg.kg ${ }^{-1}$ (median $21.11 \pm 1.63$ ), Cr, 3.03-64.02 mg.kg-1 (median $17.46 \pm 1.96$ ), Fe, 4.45-20.64 mg.kg-1 (median $8.11 \pm 0.58$ ), Mn 263.72-2368.31 mg.kg-1 (median $1370.95 \pm 71.53), \mathrm{V}, 43.45-181.79 \mathrm{mg} . \mathrm{kg}^{-1}$ (median $96.72 \pm 4.31$ ) and $\mathrm{Zn}, 63.16-373.58$ mg.kg-1 (median $204.57 \pm 12.03$ ).

The results of metal content from districts $A, B$ and $C$ confirmed that maximal highest concentration of $\mathrm{Hg}$ was in site $\mathrm{A}(1.31)>$ site $\mathrm{C}(0.25)>$ site $\mathrm{B}(0.19), \mathrm{Cd}$ in site $\mathrm{A}(1.18)>$ site $\mathrm{C}(0.43)>$ site $\mathrm{B}(0.31)$, Fe in site $A(20.64) \approx$ site $B(20.64) \approx$ site $C(20.49), C r$ in site $A(63.97) \approx$ site $B(63.54) \approx$ site $C(64.01)$, $\mathrm{Cu}$ in site $\mathrm{C}(98.83) \approx$ site $\mathrm{A}(90.66)>$ site $\mathrm{B}(55.96) ; \mathrm{V}$ in site $\mathrm{A}(154.48)>$ site $\mathrm{A}(181.79) \approx$ site $\mathrm{B}(181.79)$, $\mathrm{Pb}$ in site $\mathrm{A}(174.24)>$ site $\mathrm{C}(162.02)>$ site $\mathrm{A}(110.03), \mathrm{Zn}$ in site $\mathrm{A}(373.59)>$ site $\mathrm{B}(331.31)>$ site $\mathrm{C}$ (331.08) and $\mathrm{Mn}$ in site A (2368) > site C (2271) $\approx$ site B (2081). Generally, the highest concentration of 
$\mathrm{Hg}, \mathrm{Pb}, \mathrm{Cd}, \mathrm{Mn}$ and $\mathrm{Zn}$ were identified in site A with a strong industry impact (steel production and metallurgical industry).

Table 1. Descriptive statistics of total concentration of $\mathrm{Cd}, \mathrm{Hg}, \mathrm{Cu}, \mathrm{Mn}, \mathrm{Pb}, \mathrm{V}, \mathrm{Zn}, \mathrm{Cr}$ and $\mathrm{Fe}\left(\mathrm{mg}^{\mathrm{k}} \mathrm{kg}^{-1}\right.$ ) in soil samples of Ostrava.

\begin{tabular}{|c|c|c|c|c|c|c|c|c|c|c|}
\hline & Statistic & $\mathrm{Hg}$ & $\mathrm{Pb}$ & $\mathrm{Cd}$ & $\mathrm{Cu}$ & $\mathrm{Cr}$ & $\mathrm{Fe}$ & Mn & V & Zn \\
\hline \multirow[t]{4}{*}{ Total } & Min & 0.08 & 11.09 & 0.05 & 4.88 & 3.03 & 4.45 & 263.72 & 43.45 & 60.91 \\
\hline & Max & 1.31 & 174.03 & 1.18 & 98.83 & 64.02 & 20.64 & 2368.31 & 181.79 & 393.08 \\
\hline & Median & 0.19 & 37.71 & 0.21 & 21.11 & 17.46 & 8.11 & 1370.92 & 96.71 & 204.569 \\
\hline & SD & 0.02 & 3.04 & 0.02 & 1.63 & 1.96 & 0.58 & 71.53 & 4.31 & 12.03 \\
\hline \multirow[t]{4}{*}{ Site A } & Min & 0.13 & 17.03 & 0.06 & 13.88 & 3.379 & 4.502 & 263.722 & 43.455 & 85.160 \\
\hline & Max & 1.31 & 174.24 & 1.18 & 90.66 & 63.974 & 20.644 & 2368.786 & 154.488 & 373.587 \\
\hline & Median & 0.34 & 56.56 & 0.265 & 27.28 & 19.75 & 9.76 & 1327.51 & 97.79 & 250.03 \\
\hline & SD & 0.05 & 3.33 & 0.05 & 1.09 & 2.793 & 0.839 & 113.230 & 5.054 & 15.707 \\
\hline \multirow[t]{4}{*}{ Site B } & Min & 0.08 & 18.22 & 0.05 & 4.88 & 3.026 & 4.455 & 557.329 & 43.455 & 63.160 \\
\hline & Max & 0.19 & 110.03 & 0.31 & 55.96 & 63.539 & 20.644 & 2081.199 & 181.798 & 331.306 \\
\hline & Median & 0.12 & 42.47 & 0.19 & 31.50 & 17.058 & 7.811 & 1370.924 & 90.593 & 195.704 \\
\hline & SD & 0.01 & 5.94 & 0.01 & 2.95 & 3.965 & 1.177 & 111.235 & 7.988 & 17.912 \\
\hline \multirow{4}{*}{ Site C } & Min & 0.09 & 11.09 & 0.06 & 15.01 & 3.03 & 4.455 & 557.329 & 69.291 & 78.906 \\
\hline & Max & 0.25 & 162.02 & 0.43 & 98.83 & 64.015 & 20.493 & 2271.312 & 181.798 & 331.081 \\
\hline & Median & 0.19 & 55.61 & 0.21 & 37.78 & 16.618 & 8.473 & 1325.369 & 104.784 & 167.727 \\
\hline & $\mathrm{SD}$ & 0.05 & 46.71 & 0.08 & 24.01 & 16.107 & 4.828 & 510.931 & 30.657 & 92.971 \\
\hline \multirow[t]{3}{*}{ Earth crust } & a & 0.08 & 16.00 & 0.13 & 47.00 & 83.00 & 46500 & 1000.00 & 90.00 & 83.000 \\
\hline & $\mathrm{b}$ & 0.05 & 17 & 0.09 & 28 & 92.0 & - & - & 97 & 67 \\
\hline & c & 0.07 & 15 & 0.1 & 55 & 100 & - & 900 & 135 & 70 \\
\hline PEL, CZ & & 0.60 & 50 & 0.40 & 50 & 40 & - & - & 50 & 100 \\
\hline$B_{n}$ & & 0.12 & 14.58 & 0.12 & 8.35 & 3.03 & 5.46 & 263.0 & 4.053 & 61.87 \\
\hline
\end{tabular}

-: no relevant data; Min: minimum, Max: maximum, SD: standard deviation; a [36], b [35], c [37]; PEL—permissible limit-Decree No. 153/2016 Coll. in CZ; $B_{n}$ —concentration of heavy metal ( $n$ ) geochemical background.

Moreover, the lowest metal concentration was found in the case of site B; however, the higher metal-contaminated soils of site $C$ are due to the nearby chemical industry, as well as being an area with high traffic due to roads connecting to the D1 highway. The highest metal concentrations, mainly $\mathrm{Hg}$ (3, 5, 15 and 17 stations), $\mathrm{Pb}(4,9,10,11,21,26$ and 27 stations), $\mathrm{Cd}(9,10,11$ stations), $\mathrm{Cr}$ (stations 3 and 15), Mn (23, 25 and 26 stations) and $\mathrm{Zn}(9,10,12$ and 25 stations) were determined. The median of $\mathrm{Hg}, \mathrm{Pb}$ and $\mathrm{Cd}$ concentrations exceeded background values and values of continental crust of metals in comparison with environmental background values and indicating that total area and sites A, B and $\mathrm{C}$ are being polluted considerably. According to comparison of maximum permissible limit values of potentially toxic metals $(\mathrm{Pb}, \mathrm{Cd}, \mathrm{Cu}, \mathrm{Cr}, \mathrm{V}$ and $\mathrm{Zn})$, the median of metal concentrations was exceeded in the case of $\mathrm{Pb}$ in sites $\mathrm{A}$ and $\mathrm{C}$ as well as $\mathrm{V}$ and $\mathrm{Mn}$ in sites $\mathrm{A}, \mathrm{B}$ and $\mathrm{C}$. Nevertheless, the maximums of metal concentrations were exceeded in several location of sites $\mathrm{A}, \mathrm{B}$ and $\mathrm{C}$.

\subsection{Pollution Assessment in Soils}

On the basis of determined heavy metal concentrations in soil samples from Ostrava, the three single indices and five total complex indices (only integrated indices) were calculated. These indices indicated pollution by individual metals ( $\mathrm{I}_{\mathrm{geo}}, \mathrm{EF}$ and $\mathrm{CF}$ ) and assessed soil quality (IPI, IPIT, PLI, $\mathrm{C}_{\mathrm{deg}}$, $\mathrm{mC}_{\mathrm{deg}}$ and $\left.\mathrm{PI}_{\text {Nemerow }}\right)$.

The single indices-geoaccumulation index ( $\left.\mathrm{I}_{\text {geo }}\right)$, enrichment factor $(\mathrm{EF})$ and contamination factor (CF)—were used to assess the anthropogenic impact of heavy metal soil contamination. The metal concentrations of the geochemical background were used for calculation of the geoaccumulation index $\left(\mathrm{I}_{\text {geo }}\right)$, and pre-industrial levels of metals were used for calculation of the contamination factor $(\mathrm{CF})$. 
The concentration of Fe was used for calculation of enrichment factors (EF); this is characterized by relative stable concentrations in soils. Figure 3 represents the results of the single indices $\mathrm{I}_{\text {geo, }} \mathrm{CF}$ and EF of heavy metals in site A, B and C, as well as the total area of Ostrava, and in these graphs the classification levels of contamination are marked (blue line).
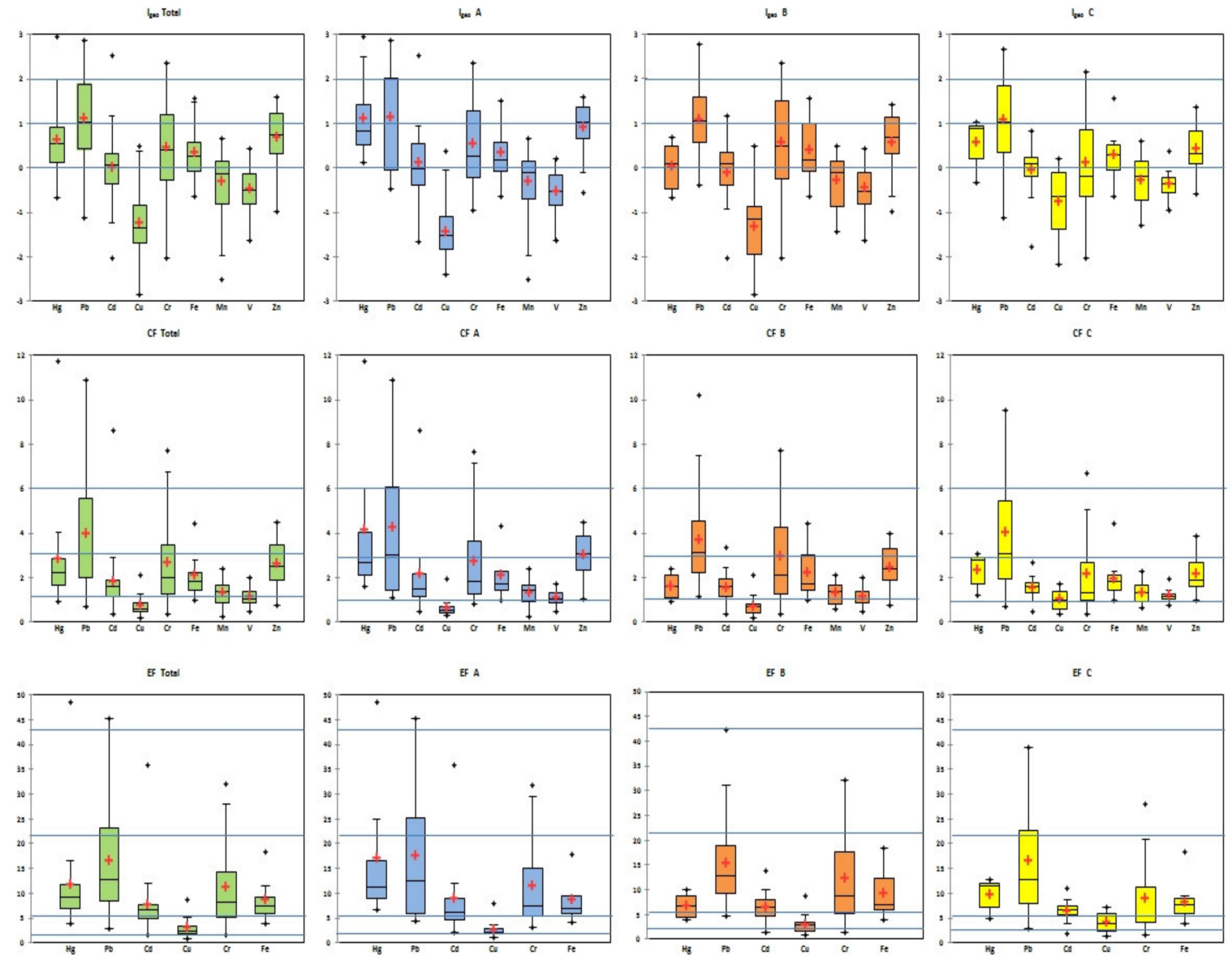

Figure 3. Box-and-whisker plot of single indices-geoaccumulation index $\left(\mathrm{I}_{\text {geo }}\right)$, contamination factor (CF) and enrichment factor (EF).

Box-and-whisker plots depict the mean, median, 1st and 3rd quartiles and extremes values (outliners) of single pollution indices calculated for soil samples in Ostrava (CZ). Boxes delineate the quartile range with an indication of the median (solid line); a small cross inside the box marks the mean.

The geoaccumulation index for $\mathrm{Cd}, \mathrm{Hg}, \mathrm{Cu}, \mathrm{Mn}, \mathrm{Pb}, \mathrm{V}, \mathrm{Zn}, \mathrm{Cr}$ and Fe varied and values below zero indicate minimal anthropogenic effects with uncontaminated levels in the case of $\mathrm{Cu}, \mathrm{V}$ and $\mathrm{Mn}$ in total area and also in sites A, B and C; nevertheless in case of $\mathrm{Cd}$ in site B and C. Values 0-1 determine that very low moderate contamination exists for $\mathrm{Hg}, \mathrm{Cr}, \mathrm{Fe}$ and $\mathrm{Zn}$ in total area and sites $\mathrm{A}, \mathrm{B}$ and $\mathrm{C}$, with an exception of Site $\mathrm{A}$ in case of $\mathrm{Hg}$ where $\mathrm{I}_{\text {geo }}$ is over 1 . Moderate contaminations were verified in the case of $\mathrm{Hg}$ in Site $\mathrm{A}$ and $\mathrm{Pb}$ in all sites and total area of Ostrava where $\mathrm{I}_{\text {geo }}$ indices were over 1. Generally, the contents of heavy metals increase in the following order, $\mathrm{Cu}<\mathrm{V}<\mathrm{Mn}<\mathrm{Cd}<\mathrm{Fe}<$ $\mathrm{Cr}<\mathrm{Zn}<\mathrm{Hg}<\mathrm{Pb}$, based on $\mathrm{I}_{\text {geo }}$ average values. The minimal enrichment of metals in soils can be attributed to natural origin and fluctuations of metals if EF values are lower than 2. In case of copper obtained, EF values confirmed the moderate enrichment of $\mathrm{Cu}$ in soil samples. The mean and median values of EF values varied from 5 to 20 and values affirmed significant enrichment of $\mathrm{Cd}, \mathrm{Hg}, \mathrm{Mn}, \mathrm{Pb}$, $\mathrm{V}, \mathrm{Zn}, \mathrm{Cr}$ and Fe in soils in total area and sites A, B and C. EF values over 20 and 40 were obtained for $\mathrm{Mn}, \mathrm{Zn}$ and $\mathrm{V}$, and ones indicated enrichment levels from very high to extremely enriched. Based on the results, the contamination factors of $\mathrm{Cu}$ and $\mathrm{V}(\mathrm{CFs}<1)$ for sites $\mathrm{A}, \mathrm{B}$ and $\mathrm{C}$ and total area of Ostrava can be regarded as localities with low contamination. 
Box-and-whisker plot depicted the mean, median, 1st and 3rd quartiles and extremes values (outliners), and boxes delineate quartile range with indication of the median (solid line); a small cross inside the box marks the mean.

The CF levels from 1 to 3 with moderate contamination levels were obtained in occurrence of $C d$, $\mathrm{Hg}, \mathrm{Mn}, \mathrm{Pb}, \mathrm{Zn}, \mathrm{Cr}$ and $\mathrm{Fe}$ with the exception of $\mathrm{Pb}$. The $\mathrm{CF}$ levels growing follows $\mathrm{Cu}<\mathrm{V}<\mathrm{Mn}<\mathrm{Cd}$ $<\mathrm{Fe}<\mathrm{Cr}<\mathrm{Zn}<\mathrm{Hg}<\mathrm{Pb}$. The $\mathrm{CF}$ levels of $\mathrm{Pb}$ varied around 4, indicating considerable contamination of soils.

In this study, the integrated indices of pollution-integrated pollution index (IPI), pollution load index (PLI), Nemerow pollution index $\left(\mathrm{PI}_{\text {Nemerow }}\right)$, degree of contamination $\left(\mathrm{C}_{\mathrm{deg}}\right)$ and modified contamination factor $\left(\mathrm{mC}_{\mathrm{deg}}\right)$-were used for assessment of soil contamination by heavy metals.

The indices of pollution IPI confirmed strong pollution of the total area in Ostrava (median 2.761, mean 2.996) and also strong pollution of sites A (median 2.88, mean 3.091), B (median 2.77, mean 2.958) and $C$ (median 2.48, mean 2.868). The mean of the threshold pollution index (IPIT) was in the case of total area 1.106, site A 1.177 , site B 1.043 and site C 1.068 , and the range of this index varied from 0.523 to 2.007 , which means the level of pollution can be considered as moderate. The pollution load index (PLI) was over 1 (median 1.562 and mean 1.648) for total area and varied from 0.702 to 3.50, and thus the total area of Ostrava has to be considered as polluted through anthropogenic activity. The median of degree of contamination $\left(C_{\mathrm{deg}}\right)$ was 18.23 for the total area of Ostrava where the median of this index also confirmed the considerable degree of contamination in case of site A (19.53), site B (18.10) and site $C$ (17.10). The minimum of degree of contamination $\left(C_{\text {deg }}\right)$ was 7.255 (low degree of contamination) and the maximal value was 41.472 (very high degree of contamination); however, the median of $C_{\operatorname{deg}}$ was 18.288 for total area where the median of this index also confirmed the considerable degree of contamination in case of site A (19.53), site B (18.10) and site C (17.10). The calculated values over limit-values of pollution status (32) according to classifications, belong to soil samples from site A and from the sampling sites with closest proximity to industrialized sites (industrial metallurgical factory and long period active mines). Whereas the modified contamination factor $\left(\mathrm{mC}_{\mathrm{deg}}\right)$ for total area of Ostrava with median 2.560 classified this locality to class as moderately contaminated and individual sites A (2.73), B (2.53) and C (2.39) can be also included in the class moderately contaminated. Thus, the maximal value of $\mathrm{mC}_{\mathrm{deg}}$ calculated 5.806 (A site) and the highest $\mathrm{mC}_{\mathrm{deg}}$ were obtained in the case industrialized sites, and this value identifies a high contamination status for this area. The median

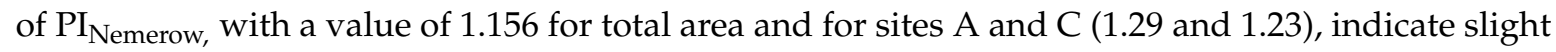
pollution and ranged from slight (nearly 1 ) to heavy pollution (4.028). Box-and-whisker plots of the integrated indices of pollution-IPI, IPIT, PLI, $\mathrm{C}_{\mathrm{deg}}, \mathrm{mC}_{\mathrm{deg}}$ and $\mathrm{PI}_{\text {Nemerow }}$, are illustrated in Figure 4.

\subsection{Identification of Pollution Sources}

\subsubsection{Correlation Analysis}

The high correlation coefficients among heavy metals indicate the similar origin of pollution sources and very low or negative correlation coefficients reflect different sources, and it probably is closely related with natural or geogenic processes $[9,43]$.

The Pearson's correlation with statistical significance at $p<0.01$ and $p<0.05$ are summarized in Table 2. From a statistical viewpoint, the correlation coefficient $(r)$ can be divided into four correlation classes: $r \leq 0.1$ low, $r$ in range 0.1-0.3 medium, $r$ in range 0.3-0.5 high and $r \geq 0.5$ mean very strong interrelationship among heavy metals. The high correlation among heavy metals could indicate that metals originated from a common pollution sources and could be characterized with a similar migration and transformation via physico-chemical conditions in the environment. 


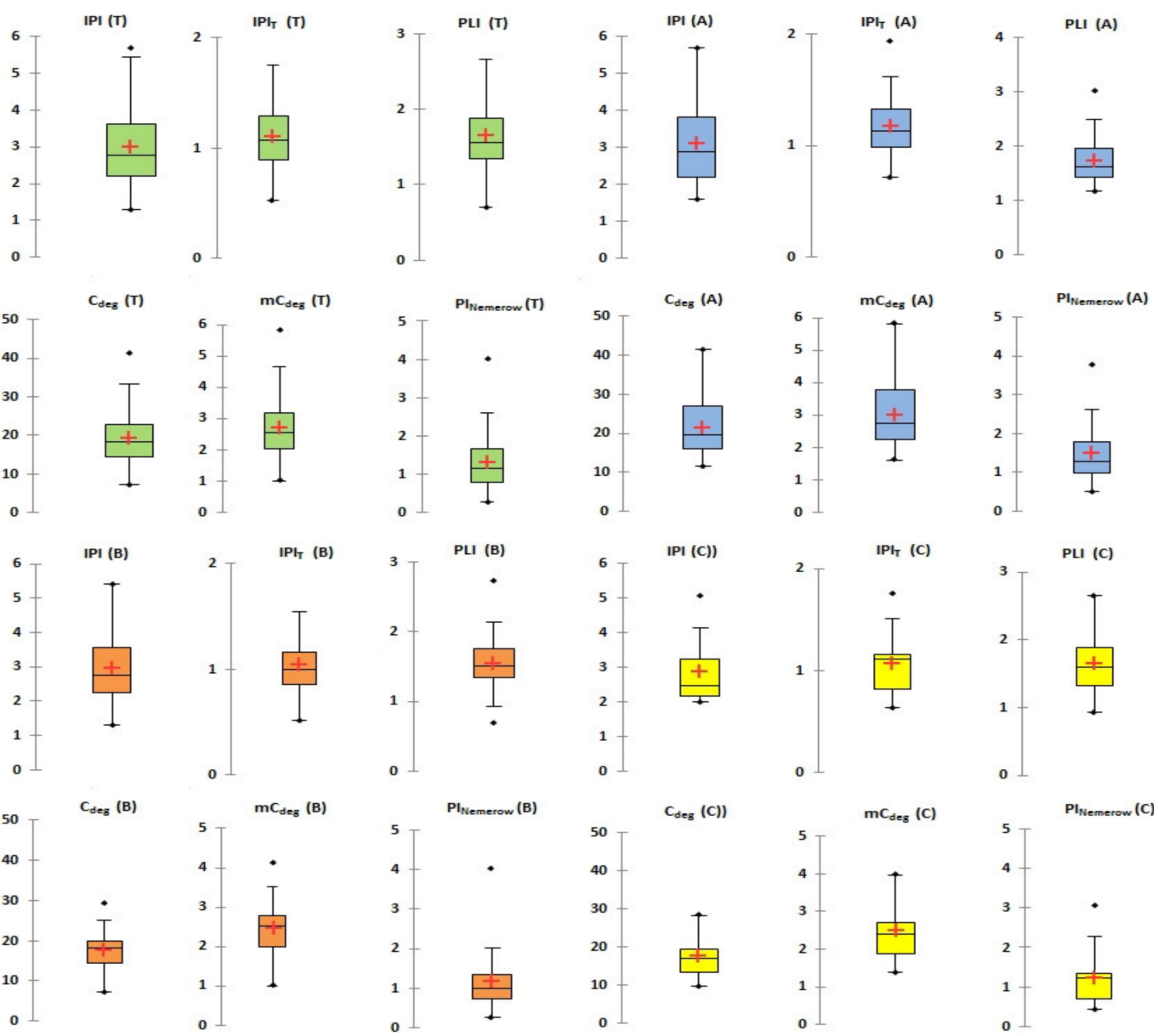

Figure 4. Box-and-whisker plot of integrated indices of pollution-integrated pollution index (IPI), integrated threshold pollution index (IPIT), pollution load index (PLI), degree of contamination $\left(\mathrm{C}_{\mathrm{deg}}\right)$, modified contamination factor $\left(\mathrm{mC}_{\mathrm{deg}}\right)$ and Nemerow pollution index $\left(\mathrm{PI}_{\text {Nemerow }}\right)$.

Table 2. Correlation matrix (Pearson) of total metal contents in soil samples from Ostrava.

\begin{tabular}{|c|c|c|c|c|c|c|c|c|c|}
\hline & Hg (T) & $\mathrm{Pb}(\mathrm{T})$ & $\mathrm{Cd}(\mathrm{T})$ & $\mathrm{Cu}(\mathrm{T})$ & $\mathrm{Cr}(\mathrm{T})$ & Fe $(T)$ & $\operatorname{Mn}(\mathrm{T})$ & $\mathrm{V}(\mathrm{T})$ & $\mathrm{Zn}(\mathrm{T})$ \\
\hline Hg (T) & 1.000 & 0.004 & 0.222 & -0.097 & 0.291 * & $0.245 *$ & 0.118 & -0.172 & 0.190 \\
\hline $\mathrm{Pb}(\mathrm{T})$ & & 1.000 & $0.351 * *$ & $0.608 * *$ & -0.050 & 0.089 & 0.197 & $0.383^{* *}$ & 0.174 \\
\hline $\mathrm{Cd}(\mathrm{T})$ & & & 1.000 & 0.111 & -0.042 & 0.105 & -0.044 & 0.035 & 0.236 \\
\hline $\mathrm{Cu}(\mathrm{T})$ & & & & 1.000 & -0.149 & -0.025 & 0.120 & $0.411 * *$ & 0.054 \\
\hline $\mathrm{Cr}(\mathrm{T})$ & & & & & 1.000 & $0.796 * *$ & 0.066 & 0.085 & 0.211 \\
\hline $\mathrm{Fe}(\mathrm{T})$ & & & & & & 1.000 & 0.138 & 0.159 & 0.128 \\
\hline $\operatorname{Mn}(\mathrm{T})$ & & & & & & & 1.000 & 0.474 * & $0.268^{* *}$ \\
\hline V (T) & & & & & & & & 1.000 & $0.407 *$ \\
\hline \multirow[t]{2}{*}{$\mathrm{Zn}(\mathrm{T})$} & & & & & & & & & 1.000 \\
\hline & Hg (A) & $\mathrm{Pb}(\mathrm{A})$ & $\mathrm{Cd}(\mathrm{A})$ & $\mathrm{Cu}(\mathrm{A})$ & $\mathrm{Cr}(\mathrm{A})$ & Fe (A) & Mn (A) & $\mathrm{V}(\mathrm{A})$ & $\mathrm{Zn}(\mathrm{A})$ \\
\hline $\mathrm{Hg}$ (A) & 1.000 & -0.143 & 0.126 & -0.193 & $0.526 * *$ & $0.422 *$ & 0.156 & -0.269 & 0.043 \\
\hline $\mathrm{Pb}(\mathrm{A})$ & & 1.000 & 0.326 & $0.586 * *$ & 0.009 & 0.313 & 0.108 & $0.471 * *$ & 0.067 \\
\hline $\mathrm{Cd}(\mathrm{A})$ & & & 1.000 & 0.057 & 0.036 & 0.281 & -0.110 & 0.027 & 0.194 \\
\hline $\mathrm{Cu}(\mathrm{A})$ & & & & 1.000 & -0.220 & 0.005 & -0.187 & 0.360 & -0.016 \\
\hline $\mathrm{Cr}(\mathrm{A})$ & & & & & 1.000 & $0.676 * *$ & 0.059 & -0.239 & 0.088 \\
\hline $\mathrm{Fe}(\mathrm{A})$ & & & & & & 1.000 & 0.259 & 0.065 & 0.035 \\
\hline $\operatorname{Mn}(\mathrm{A})$ & & & & & & & 1.000 & 0.368 * & -0.102 \\
\hline V (A) & & & & & & & & 1.000 & 0.361 \\
\hline Zn (A) & & & & & & & & & 1.000 \\
\hline
\end{tabular}


Table 2. Cont.

\begin{tabular}{|c|c|c|c|c|c|c|c|c|c|}
\hline & Hg (B) & $\mathrm{Pb}(\mathrm{B})$ & Cd (B) & $\mathrm{Cu}(\mathrm{B})$ & $\mathrm{Cr}(\mathrm{B})$ & Fe (B) & Mn (B) & V (B) & Zn (B) \\
\hline Hg (B) & 1.000 & 0.334 & $0.551 * *$ & 0.382 & 0.072 & 0.037 & 0.212 & 0.235 & 0.180 \\
\hline $\mathrm{Pb}(\mathrm{B})$ & & 1.000 & $0.587^{* *}$ & $0.605 * *$ & -0.204 & -0.244 & 0.139 & 0.320 & 0.282 \\
\hline Cd (B) & & & 1.000 & $0.645 * *$ & -0.399 & -0.319 & 0.175 & 0.164 & 0.230 \\
\hline $\mathrm{Cu}(\mathrm{B})$ & & & & 1.000 & -0.028 & 0.016 & 0.196 & $0.515^{* *}$ & $0.438 *$ \\
\hline $\mathrm{Cr}(\mathrm{B})$ & & & & & 1.000 & $0.901 * *$ & -0.040 & 0.286 & 0.090 \\
\hline $\mathrm{Fe}(\mathrm{B})$ & & & & & & 1.000 & -0.070 & 0.221 & 0.021 \\
\hline Mn (B) & & & & & & & 1.000 & 0.495 * & $0.741 * *$ \\
\hline V (B) & & & & & & & & 1.000 & $0.720 * *$ \\
\hline \multirow[t]{2}{*}{$\mathrm{Zn}(\mathrm{B})$} & & & & & & & & & 1.000 \\
\hline & $\mathrm{Hg}(\mathrm{C})$ & $\mathrm{Pb}(\mathrm{C})$ & $\mathrm{Cd}(\mathrm{C})$ & $\mathrm{Cu}(\mathrm{C})$ & $\mathrm{Cr}(\mathrm{C})$ & $\mathrm{Fe}(\mathrm{C})$ & $\operatorname{Mn}(\mathrm{C})$ & $\mathrm{V}(\mathrm{C})$ & $\mathrm{Zn}(\mathrm{C})$ \\
\hline $\mathrm{Hg}(\mathrm{C})$ & 1.000 & 0.513 & 0.240 & $0.591 *$ & 0.162 & 0.239 & 0.261 & -0.037 & 0.277 \\
\hline $\mathrm{Pb}(\mathrm{C})$ & & 1.000 & 0.429 & $0.893^{* *}$ & 0.099 & 0.141 & 0.484 & 0.441 & 0.219 \\
\hline $\mathrm{Cd}(\mathrm{C})$ & & & 1.000 & 0.336 & 0.121 & -0.101 & -0.055 & 0.252 & 0.169 \\
\hline $\mathrm{Cu}(\mathrm{C})$ & & & & 1.000 & -0.102 & -0.039 & 0.499 & 0.265 & 0.125 \\
\hline $\mathrm{Cr}(\mathrm{C})$ & & & & & 1.000 & $0.828^{* *}$ & 0.312 & 0.300 & $0.787^{* *}$ \\
\hline $\mathrm{Fe}(\mathrm{C})$ & & & & & & 1.000 & 0.291 & 0.271 & $0.727 * *$ \\
\hline $\operatorname{Mn}(C)$ & & & & & & & 1.000 & $0.699 * *$ & 0.412 \\
\hline V (C) & & & & & & & & 1.000 & 0.270 \\
\hline $\mathrm{Zn}(\mathrm{C})$ & & & & & & & & & 1.000 \\
\hline
\end{tabular}

${ }^{*}$ Coefficients correlations are significant at $p<0.05$ (2-tailed); ${ }^{* *}$ Coefficients correlations are significant at $p<0.01$ (2-tailed).

The high correlation among heavy metals observed in soils significantly reflect the anthropogenic input from industrial activities. Low or negative correlation of heavy metals in soils can also refer to others metal sources relating to natural processes [40-43].

The correlations in total area $(T)$ were as follows: very strong correlation $\mathrm{Fe}-\mathrm{Cr}(0.796), \mathrm{Pb}-\mathrm{Cu}$ (0.608) and high correlation among $\mathrm{Pb}-\mathrm{Cd}(0.351), \mathrm{Pb}-\mathrm{V}$ (0.383), $\mathrm{Cu}-\mathrm{V}(0.441), \mathrm{Mn}-\mathrm{V}(0.474)$ and $\mathrm{V}-\mathrm{Zn}$ (0.407). Detailed analysis of the correlation matrix of sites A, B and C identified various pollution sources of heavy metals.

In Site A, very strong positive correlations were identified among $\mathrm{Cr}-\mathrm{Fe}(0.676), \mathrm{Cr}-\mathrm{Hg}(0.526)$ and $\mathrm{Cu}-\mathrm{Pb}(0.586)$, high correlation were among Fe- $\mathrm{Hg}(0.422), \mathrm{Pb}-\mathrm{V}(0.471)$ and $\mathrm{V}-\mathrm{Mn}(0.368)$. In Site $\mathrm{B}$ very strong correlations were among $\mathrm{Cr}-\mathrm{Fe}$ (0.901), $\mathrm{Mn}-\mathrm{Zn}(0.741), \mathrm{V}-\mathrm{Zn}(0.720), \mathrm{Hg}-\mathrm{Cd}(0.551)$, $\mathrm{Cd}-\mathrm{Pb}(0.587), \mathrm{Pb}-\mathrm{Cu}(0.605), \mathrm{Cd}-\mathrm{Cu}(0.645)$ and $\mathrm{Cu}-\mathrm{V}(0.515)$. High correlations were over 0.3 in the case $\mathrm{Hg}-\mathrm{Pb}(0.334), \mathrm{Hg}-\mathrm{Cu}(0.382), \mathrm{Pb}-\mathrm{V}(0.320), \mathrm{Cu}-\mathrm{Zn}(0.483)$ and $\mathrm{Mn}-\mathrm{V}$ (0.495). In Site $\mathrm{C}$ very strong correlations were in the cases of $\mathrm{Pb}-\mathrm{Cu}$ (0.893), $\mathrm{Cr}-\mathrm{Fe}$ (0.828), $\mathrm{Cr}-\mathrm{Zn}(0.787), \mathrm{Fe}-\mathrm{Zn}$ (0.727), $\mathrm{Mn}-\mathrm{V}$ (0.699), $\mathrm{Hg}-\mathrm{Pb}(0.513)$ and $\mathrm{Hg}-\mathrm{Cu}(0.591)$. High correlation was confirmed for $\mathrm{Pb}-\mathrm{Cd}(0.429)$, $\mathrm{Pb}-\mathrm{Mn}$ (0.484), $\mathrm{Pb}-\mathrm{V}$ (0.441), $\mathrm{Cd}-\mathrm{Cu}$ (0.336), $\mathrm{Cu}-\mathrm{Mn}$ (0.499), $\mathrm{Cr}-\mathrm{Mn}$ (0.312 and $\mathrm{Mn}-\mathrm{Zn}$ (0.412).

For $\mathrm{Cr}-\mathrm{Fe}, \mathrm{Pb}-\mathrm{Cu}$ and $\mathrm{Pb}-\mathrm{V}$ the correlations were strong and high in all cases (total area, sites $\mathrm{A}, \mathrm{B}$ and $\mathrm{C}$ ) and relationships decreased $\mathrm{Cr}-\mathrm{Fe}(0.901-\mathrm{B}, 0.893-\mathrm{C}, 0.796-\mathrm{T}, 0.676-\mathrm{A}), \mathrm{Pb}-\mathrm{Cu}(0.893-\mathrm{C}$, $0.608-\mathrm{T}, 0.605-\mathrm{B}, 0.586-\mathrm{A})$ and $\mathrm{Pb}-\mathrm{V}(0.471-\mathrm{A}, 0.441-\mathrm{C}, 0.383-\mathrm{T}, 0.320-\mathrm{B})$.

The high and strong ( $r$ in the range from 0.3 to over 0.5 ) interrelationships were also for $\mathrm{V}-\mathrm{Mn}$ and increased $0.368-\mathrm{A}, 0.474-\mathrm{T}, 0.495-\mathrm{B}, 0.699-\mathrm{C}$. The strong and positive correlations indicate the conjoint main sources of heavy metals resulted in these areas from industry, combustion and traffic. From these dependencies obtained from the correlation analysis of total area, we can assume that the heavy metals as pollutants exist in three main groups $\mathrm{Fe}-\mathrm{Cr}, \mathrm{Pb}-\mathrm{Cu}$ and $\mathrm{Mn}-\mathrm{V}$.

\subsubsection{Hierarchical Cluster Analysis (HCA)}

The dendrograms of hierarchical cluster analysis (HCA) of heavy metals concentration are presented in Figure 5. Hierarchical cluster analysis (HCA) identified several groups of association among metals in relation with area, and the metals associated in a group originated from the same 
pollution sources. In the case of the highly industrialized area, A, HCA identified four groups: Group I includes $\mathrm{Fe}-\mathrm{Cr}$ and $\mathrm{Hg}$ joined this group, $\mathrm{Pb}$ and $\mathrm{Cu}$ formed Group II; Group III contain $\mathrm{Mn}$ and V, and IV Group consist metals $\mathrm{Cd}-\mathrm{Zn}$. The HCA analysis confirmed three groups of associated metals in area B, Group I are formed $\mathrm{Fe}-\mathrm{Cr}$, Group II include V-Mn and $\mathrm{Zn}$, and Group III consist $\mathrm{Cu}, \mathrm{Pb}$, $\mathrm{Cd}$ and $\mathrm{Hg}$. The three groups were identified also in area C; Group I- $\mathrm{Cr}$ and Fe with Zn, Group II $\mathrm{Mn}-\mathrm{V}$ and group III $\mathrm{Pb}-\mathrm{Cu}$ and $\mathrm{Hg}$. Thereby the total area characterized four groups: Group I- $\mathrm{Cr}$ and $\mathrm{Fe}$, Group II- $\mathrm{Mn}-\mathrm{V}$ with $\mathrm{Zn}$, group III- $\mathrm{Pb}-\mathrm{Cu}$ and group IV- $\mathrm{Cd}-\mathrm{Hg}$. The correlation analysis CA (Table 2) also identified similar heavy metal interrelationships. The results from HCA analysis confirmed that grouped metals originated from the same pollution sources. The high content of Mn and Fe could be originated from weathering of parent materials. The presence of Fe and Mn could be indirect indicators of the $\mathrm{Fe} / \mathrm{Mn}$ oxides in soils that influence heavy metals behavior in soils. Metals $\mathrm{Pb}$, $\mathrm{Cu}$ and $\mathrm{Cd}$, together with $\mathrm{Hg}$ resulted only from anthropogenic sources, such as industry, metallurgy, typical local combustion of low quality coal and different traffic intensity.
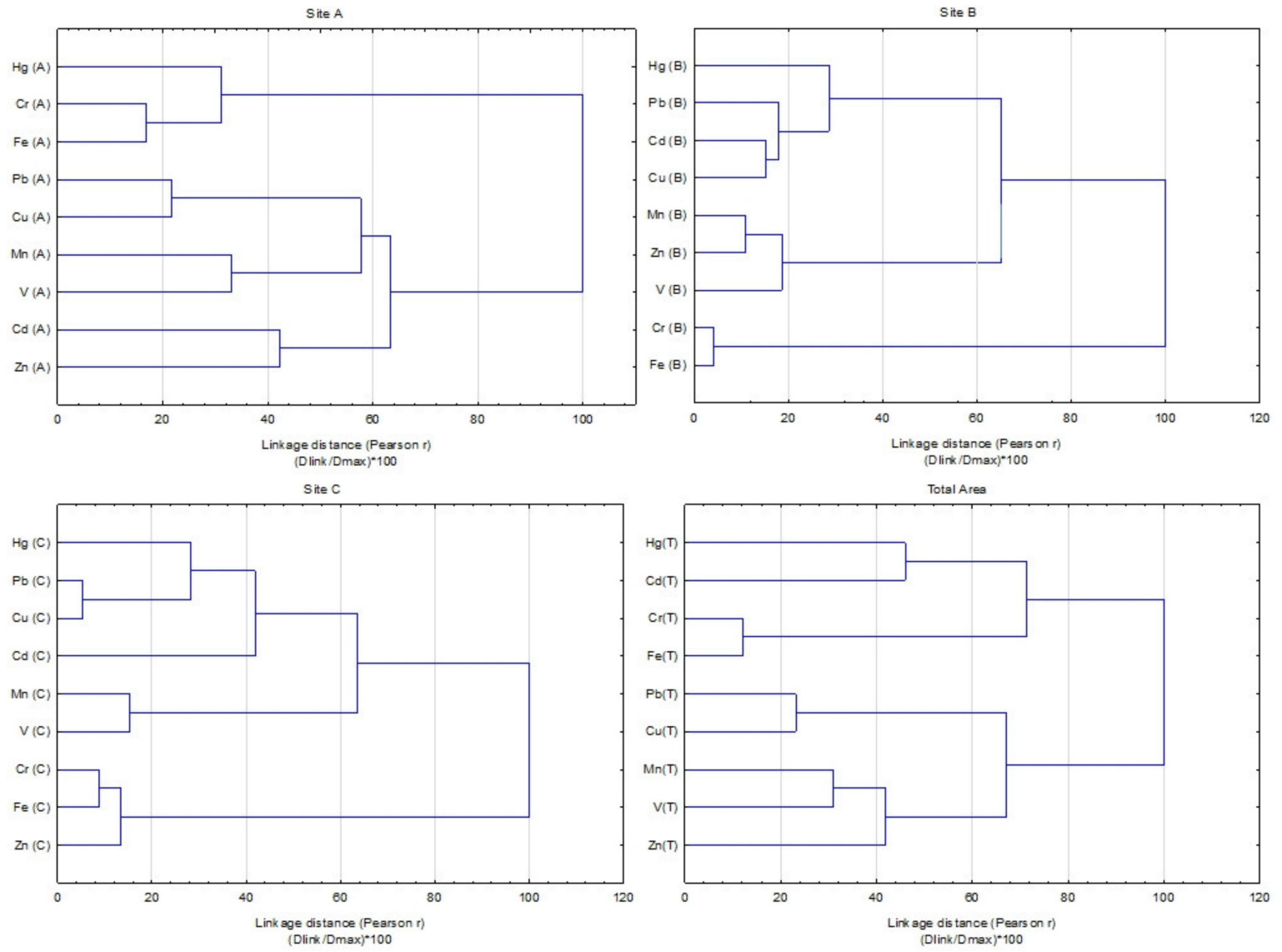

Figure 5. Dendrogram derived from hierarchical cluster analysis (HCA) of the heavy metal contents in the soils (Ward's agglomeration method, Pearson $r$ distance).

\subsubsection{Principal Component Analysis (PCA)/Factor Analysis (FA)}

Multivariate statistical methods PCA/FA were performed to identify other sources and origins of the heavy metals in soils from three various sites of Ostrava (A, B and C). The Figures 6 and 7 present the results obtained from PCA/FA. 

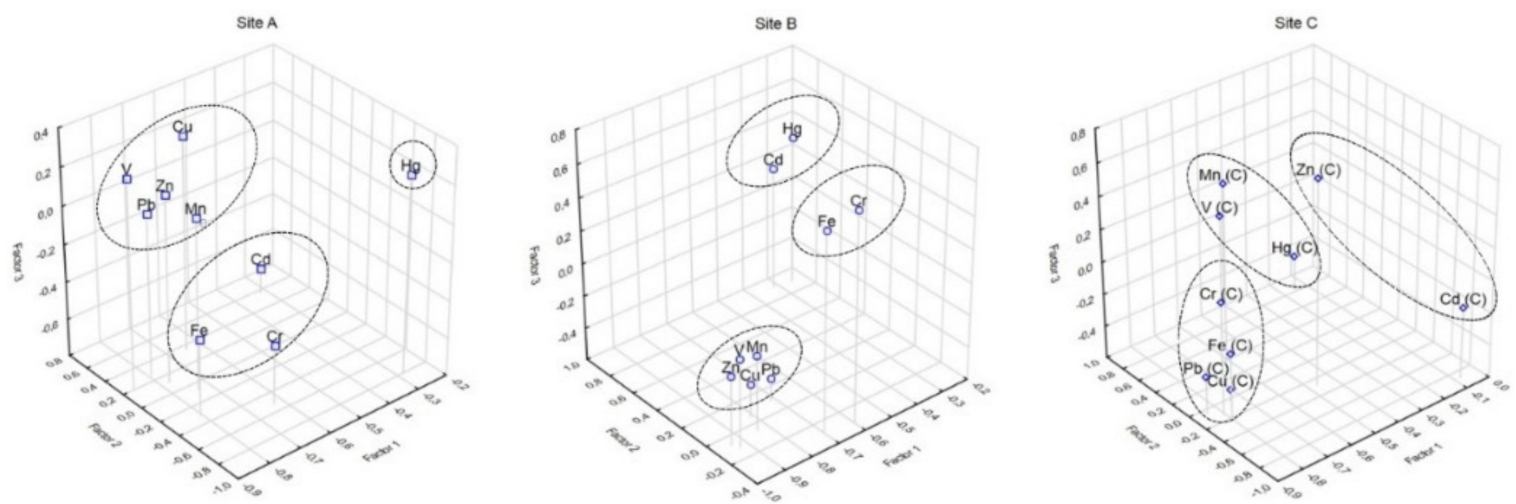

Figure 6. PCA/FA analysis results of $\mathrm{Cd}, \mathrm{Hg}, \mathrm{Cu}, \mathrm{Mn}, \mathrm{Pb}, \mathrm{V}, \mathrm{Zn}, \mathrm{Cr}$ and $\mathrm{Fe}$ in soils of Ostrava (rotation: unrotated; extraction: principal components).
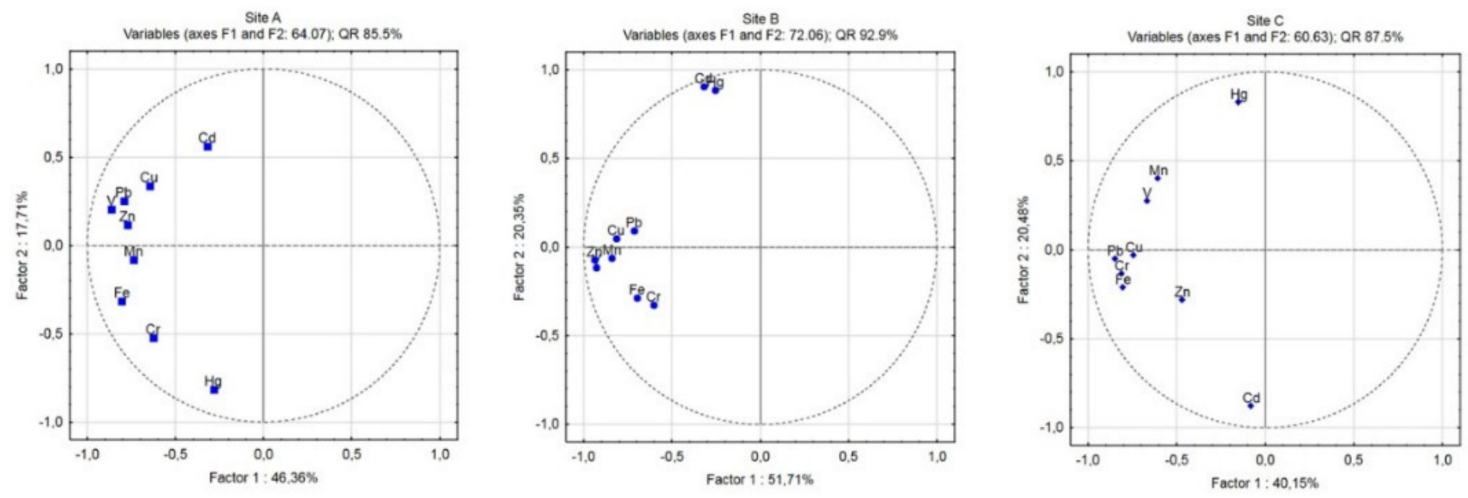

Figure 7. PCA loading plots of the first 2 principal components (F1, F2).

Principal component analyses with factor analysis were applied for assessment and evaluation of the origin identification of metals in soils. The three principal components were extracted with eigenvalues over 1.0.

The results obtained from PCA/FA analysis for metals in soils showed that in the A site the first principal component (F1) described $46.36 \%$ of the total variance with high positive loadings $\mathrm{V}(0.922)$ $\mathrm{Cu}(0.801)$ and $\mathrm{Zn} \cong \mathrm{Pb}(0.765,0.769)$; the second principal component (F2) explained $17.71 \%$ of total variance and included $\mathrm{Cr}(0.939)$ and $\mathrm{Fe}$ (0.862); and the third principal component (F3) consists of $\mathrm{Cd}$ (0.874) and explains $12.68 \%$ of the total variance. The heavy metals $\mathrm{Cu}$ and $\mathrm{Zn}(\mathrm{Pb})$ can be used for evaluation of long-term anthropogenic contamination mainly via stainless steel production and coal mine activities; high positive loadings of $\mathrm{V}$ can be attributed to the emissions from steel production of special steels, mainly high-strength steel. The other source of $\mathrm{Cu}$ and $\mathrm{Pb}$ is also attributed to the long-term high traffic situation in this area. The second principal component (F2) contains Fe (0.862) and $\mathrm{Cr}(0.939)$ and the main sources might be similar, such as distribution through fumes from industry (iron productions, blast furnace, roller factory, coke-oven plant, etc.). The third principal component (F3) consists from $\mathrm{Cd}(0.874)$ and explains $12.68 \%$ of the total variance and the main sources are extensive industry production.

In Site B, the FA/PCA results confirmed anthropogenic sources of metals. The first component consists of $\mathrm{Cu}$ (0.895), $\mathrm{Zn}(0.891), \mathrm{Pb}(0.848), \mathrm{V}(0.817)$ and $\mathrm{Mn}(0.784)$ and explains $51.71 \%$ of the total variance. The sources of these metals are the same as in Site A with the exception of Mn. The anthropogenic sources are the same as in Site A, where the main contributions are from enormous industry production. The second principal component explain $20.34 \%$ of total variance and includes $\mathrm{Hg}$ (0.973) and $\mathrm{Cd}(0.960)$ and suggests the main contributions of these metals might be attributed to local coal combustions. The third component accounted for $15.31 \%$ of the total variance and contributed to $\mathrm{Cr}(0.953)$ and $\mathrm{Fe}$ (0.932), and these metals indicated a similar sources (metallurgical industry). 
In the Site $\mathrm{C}$, the results obtained from FA/PCA analysis were slightly different. The first principal component explains $40.14 \%$ of total variance with high values for $\mathrm{Cu}(0.905), \mathrm{Pb}(0.902), \mathrm{Fe}(0.794)$ and $\mathrm{Cr}$ (0.621). The metal $\mathrm{Cu}$ and $\mathrm{Pb}$ indicated long-term pollution from two main sources, steelworks industry and high vehicle traffic density. The $\mathrm{Fe}$ and $\mathrm{Cr}$ released from metallurgical activities in this region, and its distribution, is also on long distance. The second principal component with $20.47 \%$ of the total variance belongs to $\mathrm{Cd}(0.814)$; the main contributions of this metals include the high level of fossil fuel, local combustions and also the applications of manure and agrochemicals in this peripheral and almost rural site in this region. The third principal component includes Mn (0.813), $\mathrm{Zn}(0.743)$ and $\mathrm{V}(0.737)$ that accounts for $16.19 \%$ of the total variance.

Due to the persistent and accumulation properties of heavy metals in soils, they can be considered as markers of long-term anthropogenic pollution. The common group of metals in Site A, B and C included $\mathrm{Fe}-\mathrm{Cr}$ with association of $\mathrm{Cd}$ in Site $\mathrm{A}$ and $\mathrm{Pb}-\mathrm{Cu}$ in Site $\mathrm{C}$. These major groups originated mainly from coal consumption (industry, metallurgy and local combustion of low-quality coal). The household local combustion of coal can be considered as potentially problematic with serious environmental and health impacts in the Ostrava region due to different fuel utilization and also with pollution emission control. The presence of $\mathrm{Pb}$ in the Ostrava region originates from the burning of coal in industries and households and metallurgy, as well as industrial wastes [10-13,16,24]. The Cu derived mainly from metal industries, steel production and also traffic.

\subsection{Ecological Risk Assessment}

The values of potential ecological risk (PERI) in the studied soil samples varied (see Figure 8). The PERI values of Site A with high industrial affected soils ranged from 112 to 654 with a median of 190 , which means a strong ecological risk, whereas approximately $45 \%$ of PERI values lied between 90 and 180 and indicated a moderate ecological risk; 31\% were between 180 and 360 that indicated a strong ecological risk; $21 \%$ were between 360 and 600 and indicated a very strong ecological risk; and 3\% were over 600 and indicated a highly strong ecological risk. The levels of PERI in Site B varied from 59 to 195 with a median of 125; this means that the area can be characterized as with a moderate ecological risk, whereas approximately $21 \%$ of PERI values lied below 90 , indicating low ecological risk; $73 \%$ were between 90 and 180 that indicated a moderate ecological risk; and 6\% were between 180 and 360 and indicated a strong ecological risk. The PERI values from soil samples from the suburban C site ranged from 73 to 266 with a median of 172 that can be marked as an area with moderate risk; approximately $55 \%$ were between 90 and 180 and $45 \%$ were between 180 and 360 .

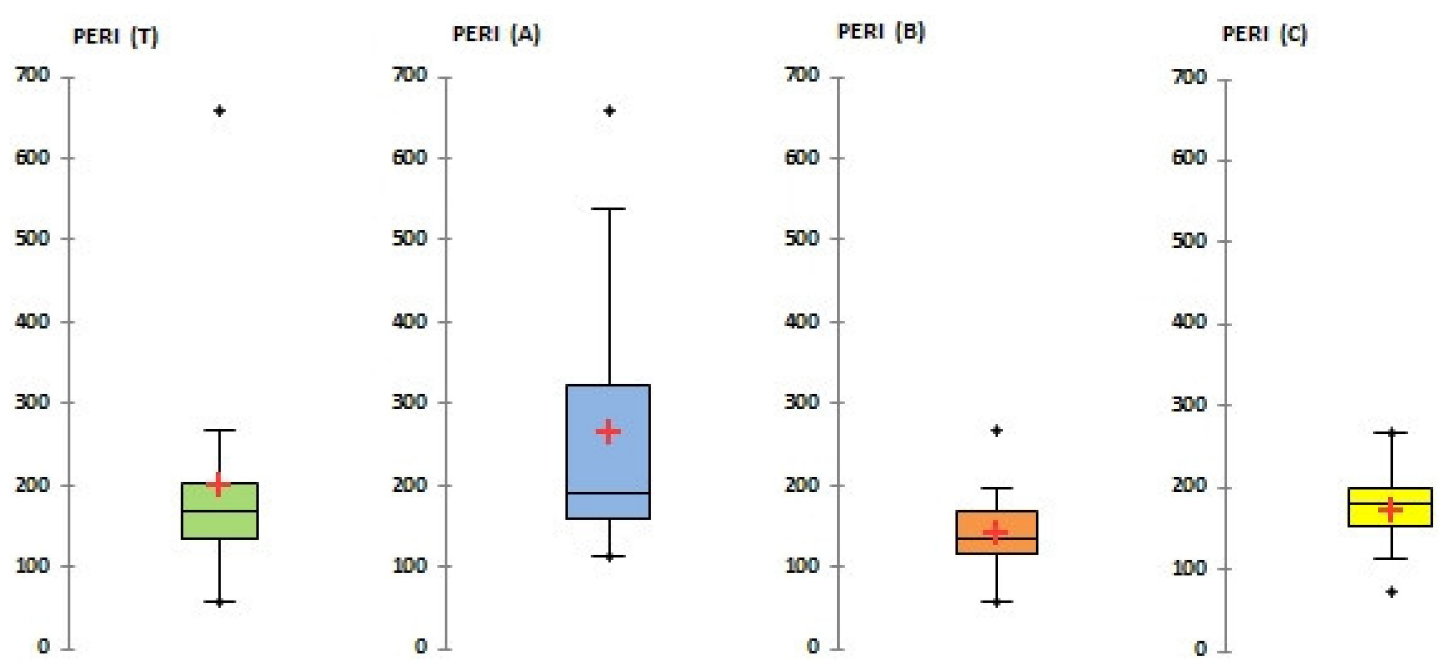

Figure 8. Box-and-whisker plot of the potential ecological risk index (PERI).

The total study area (T) can be assigned as with a moderate ecological risk (PERI 168), but approximately $46 \%$ of all PERI values lied between 90 and 180 and indicated a moderate ecological 
risk; $41 \%$ were between 180 and 360 that indicated a strong ecological risk; $10 \%$ were between 360 and 600 and indicated a very strong ecological risk; and 3\% were over 600 and indicated a highly strong ecological risk.

Box-and-whisker plots depicted mean, median, 1st and 3rd quartiles and extremes values (outliners); boxes delineate quartile range with indication of the median (solid line); and a small cross inside the box marks the mean.

\subsection{Health Risk Assessment}

The human health risk assessment was evaluated using non-carcinogenic hazards by calculation of the hazard index (HI) and carcinogenic risk over lifetime (LCR) for adult and child (Equations (1)-(6)). The individual organism is exposed via three pathways (oral ingestion, inhalation and dermal contact) and these exposures are calculated as chronic daily intake (Table S3, Supplementary Materials) with RfD (Table S4, Supplementary Materials).

Hazard index $(H I)$ indicates the cumulative non-carcinogenic risk and the highest values of $H I$ were in the case $\mathrm{Pb}$ in Site $\mathrm{C}$ for adults and all areas for children; the cumulative hazard index was estimated for all areas for $\mathrm{V}$ for children. In these cases, the HIs were over 1 and adverse health effects are possible.

The mean $\mathrm{HI}$ values of children's non carcinogenic risk for total area decrease in the following order: $\mathrm{V}>\mathrm{Pb}>\mathrm{Zn}>\mathrm{Cr}>\mathrm{Mn}>\mathrm{Hg}>\mathrm{Cu}>\mathrm{Cd}>\mathrm{Fe}$.

The non-carcinogenic risk of exposure of heavy metals from soils for children is higher due to different physiological properties in contrast to adults. From Table 3 it can be seen that $H I$ values for adults and children (Table 3 ) are different for the values for individual metals as well as for the studied areas. For children, the riskiest site is A.

Table 3. Cumulative hazard index (HI) for non-carcinogenic risk.

\begin{tabular}{ccccccccccc}
\hline \multirow{6}{*}{ Adult } & Hg & Pb & Cd & Cu & Cr & Fe & Mn & V & Zn \\
& Total & $8.71 .10^{-3}$ & $1.48 .10^{-1}$ & $9.63 .10^{-4}$ & $7.83 .10^{-3}$ & $8.00 .10^{-2}$ & $1.59 .10^{-4}$ & $3.77 .10^{-2}$ & $1.90 .10^{-1}$ & $9.38 .10^{-2}$ \\
& Site A & $1.56 .10^{-2}$ & $2.22 .10^{-1}$ & $1.21 .10^{-3}$ & $1.01 .10^{-2}$ & $9.05 .10^{-2}$ & $1.92 .10^{-4}$ & $3.65 .10^{-2}$ & $1.92 .10^{-1}$ & $1.15 .10^{-1}$ \\
& Site B & $5.50 .10^{-3}$ & $1.67 .10^{-1}$ & $8.71 .10^{-4}$ & $1.17 .10^{-2}$ & $7.82 .10^{-2}$ & $1.53 .10^{-4}$ & $3.77 .10^{-2}$ & $1.78 .10^{-1}$ & $8.97 .10^{-2}$ \\
& Site C & $8.71 .10^{-3}$ & $2.19 .10^{-0}$ & $9.63 .10^{-4}$ & $1.40 .10^{-2}$ & $7.62 .10^{-2}$ & $1.66 .10^{-4}$ & $3.65 .10^{-2}$ & $2.06 .10^{-1}$ & $7.69 .10^{-2}$ \\
\hline \multirow{6}{*}{ Child } & Total & $8.11 .10^{-2}$ & $1.38 .10^{-0}$ & $8.97 .10^{-3}$ & $7.29 .10^{-2}$ & $7.46 .10^{-1}$ & $1.48 .10^{-3}$ & $3.51 .10^{-1}$ & $1.77 .10^{-0}$ & $8.74 .10^{-1}$ \\
& Site A & $1.45 .10^{-1}$ & $2.07 .10^{-0}$ & $1.13 .10^{-2}$ & $9.42 .10^{-2}$ & $8.43 .10^{-1}$ & $1.79 .10^{-3}$ & $3.40 .10^{-1}$ & $1.79 .10^{-0}$ & $1.07 .10^{-0}$ \\
& Site B & $5.12 .10^{-2}$ & $1.55 .10^{-0}$ & $8.11 .10^{-3}$ & $1.09 .10^{-2}$ & $7.28 .10^{-1}$ & $1.43 .10^{-3}$ & $3.51 .10^{-1}$ & $1.66 .10^{-0}$ & $8.36 .10^{-1}$ \\
& Site C & $8.11 .10^{-2}$ & $2.04 .10^{-0}$ & $8.97 .10^{-3}$ & $1.30 .10^{-2}$ & $7.10 .10^{-1}$ & $1.55 .10^{-3}$ & $3.40 .10^{-1}$ & $1.92 .10^{-0}$ & $7.16 .10^{-1}$ \\
\hline
\end{tabular}

The carcinogenic risk of $\mathrm{Pb}, \mathrm{Cd}$ and $\mathrm{Cr}$ via non-dietary exposure in soils were calculated and its sum expressed total cancer risk over a lifetime $(L C R)$ (Table 4). The range of tolerable values $\left(1.0 \times 10^{-6}\right.$ to $1.0 \times 10^{-4}$ ) was obtained in the case of $\mathrm{Pb}, \mathrm{Cd}$ and $\mathrm{Cr}$ for the adult across the whole study area and the acceptable threshold limit for adults were $1.20 \times 10^{-4}$ for $\mathrm{Cr}$.

Table 4. Total carcinogenic risk over lifetime (LCR) for adult and child.

\begin{tabular}{ccccc}
\hline \multirow{6}{*}{ Adults } & & Pb & Cd & Cr \\
\hline \multirow{7}{*}{ Child } & Total & $4.41 .10^{-6}$ & $1.82 .10^{-5}$ & $1.20 .10^{-4}$ \\
& Site A & $6.61 .10^{-6}$ & $2.30 .10^{-5}$ & $1.36 .10^{-4}$ \\
& Site B & $4.96 .10^{-6}$ & $1.65 .10^{-5}$ & $1.17 .10^{-4}$ \\
& Site C & $6.50 .10^{-6}$ & $1.82 .10^{-5}$ & $1.14 .10^{-4}$ \\
\hline \multirow{4}{*}{ Total } & $4.11 .10^{-5}$ & $1.69 .10^{-4}$ & $1.12 .10^{-3}$ \\
& Site A & $6.16 .10^{-5}$ & $2.14 .10^{-4}$ & $1.27 .10^{-3}$ \\
& Site B & $4.62 .10^{-5}$ & $1.53 .10^{-4}$ & $1.09 .10^{-3}$ \\
& Site C & $6.06 .10^{-5}$ & $1.69 .10^{-4}$ & $1.06 .10^{-3}$ \\
\hline
\end{tabular}


The range of carcinogenic risk levels could be characterized in detail based on the level range: the very low $\left(<10^{-6}\right)$, low $\left(10^{-6}-10^{-5}\right)$, medium $\left(10^{-5}-10^{-4}\right)$, high $\left(10^{-4}-10^{-3}\right)$, and very high $\left(>-10^{-3}\right)$ [58-60]. For adults, the low carcinogenic risk is for $\mathrm{Pb}$, medium is for $\mathrm{Cd}$ and high is for $\mathrm{Cr}$.

There is a medium carcinogenic risk for a child in the case of $\mathrm{Pb}$, but with a high risk for $\mathrm{Cd}$ and very high for $\mathrm{Cr}$. Generally, it is assumed that the level of $\mathrm{Cd}$ and $\mathrm{Cr}$ for children is not acceptable and exceeded the acceptable threshold values in whole area. The exceeded values of $10^{-4}$ in the case $\mathrm{Cd}$ and $\mathrm{Cr}$ for a child and in the case of $\mathrm{Cr}$ for adult expresses a carcinogenic risk to humans.

\section{Conclusions}

This study presents a detailed study of heavy metal pollution in soils of Ostrava with regard to type of site (industrial, urban or suburban with traffic load). The main influence on the metal distribution and its accumulation in soil were due to the type of land used (industrial, urban) and transport and represent a high risk for soil and environment pollution, as well as for human health. According the heavy metal assessment in soil from Ostrava and the interpretation of the obtained results, it can be stated that

- $\quad$ on the basis of $\mathrm{I}_{\text {geo }}$ and $\mathrm{CF}$ values, the levels of heavy metals risen in the following order $\mathrm{Cu}<\mathrm{V}$ $<\mathrm{Mn}<\mathrm{Cd}<\mathrm{Fe}<\mathrm{Cr}<\mathrm{Zn}<\mathrm{Hg}<\mathrm{Pb}$;

- indices of pollution confirmed anthropogenic pollution of the total area in Ostrava from strong to moderate levels;

- results from correlation analysis confirmed the assumption that heavy metals in soils create three major groups ( $\mathrm{Fe}-\mathrm{Cr}, \mathrm{Pb}-\mathrm{Cu}$ and $\mathrm{Mn}-\mathrm{V})$, and hierarchical cluster analysis identified several groups among heavy metals in relation to area and common pollution source of heavy metals, whereas principal component analyses with factor analysis were applied for pollution assessment and identification of the origin source of heavy metals;

- values of potential ecological risk index varied, and its value indicate a moderate ecological risk, whereas several sites with very strong ecological risk and highly strong ecological risk exist in Ostrava; and

- a serious health carcinogenic risk was identified in the case of $\mathrm{Pb}$, and the high risk is for $\mathrm{Cd}$ and very high for $\mathrm{Cr}$ for children.

Supplementary Materials: The following are available online at http://www.mdpi.com/1660-4601/16/22/4495/s1, Table S1: Matrix composition of METRANAL 34 - loam soil with higher contents of elements. Table S2: Formula and limit value of pollution indices calculated in this study. Table S3: Chronic daily intake (CDI) of metals. Table S4: RfD of different metals for different exposure pathway [49-52,59,60].

Author Contributions: H.D.W.-author of text, experimental work and data treatment, S.M. and P.C.—experimental work, J.P.—-text review and data treatment

Funding: This research was funded by funded by the Faculty of Chemistry (Brno University of Technology) grants FCH-S-19-5971 and "Pollution of the environment and possibilities of elimination of contaminants" and by the EU Regional Development Fund within the Operational Programme Research, Development and Education under the aegis of Ministry of Education, Youth and Sports of the Czech Republic; Project number CZ.02.1.01/0.0/0.0/17_049/0008426.

Conflicts of Interest: The authors declare no conflict of interest.

\section{References}

1. Wang, J.Z.; Peng, S.C.; Chen, T.H.; Zhang, L. Occurrence, source identification and ecological risk evaluation of metal elements in surface sediment: Toward a comprehensive understanding of heavy metal pollution in Chaohu Lake, Eastern China. Environ. Sci. Pollut. Res. 2016, 23, 307-314. [CrossRef]

2. Gabarrón, M.; Faz, A.; Martínez-Martínez, S.; Zornoza, R.; Acosta, J.A. Assessment of metals behaviour in industrial soil using sequential extraction, multivariable analysis and a geostatistical approach. J. Geochem. Explor. 2017, 172, 174-183. [CrossRef] 
3. Peña-Icart, M.; Pereira-Filho, E.R.; Fialho, L.L.; Nóbrega, J.A.; Alonso-Hernández, C.; Bolaños-Alvarez, Y.; Mario, S. Combining contamination indexes, sediment quality guidelines and multivariate data analysis for metal pollution assessment in marine sediments of Cienfuegos Bay, Cuba. Chemosphere 2017, 168, 1267-1276. [CrossRef]

4. Qian, Y.; Gallagher, F.; Deng, Y.; Wu, M.; Feng, H. Risk assessment and interpretation of heavy metal contaminated soils on an urban brownfield site in New York metropolitan area. Environ. Sci. Pollut. Res. 2017, 24, 23549-23558. [CrossRef]

5. Xia, X.; Yang, Z.; Li, G.; Yu, T.; Mutelo, A.M. Practicability of monitoring soil Cd, Hg, and Pb pollution based on a geochemical survey in China. Chemosphere 2017, 172, 217-224. [CrossRef]

6. Wu, W.; Wu, P.; Yang, F.; Sun, D.-L.; Zhang, D.-X.; Zhou, Y.-K. Assessment of heavy metal pollution and human health risks in urban soils around an electronics manufacturing facility. Sci. Total Environ. 2018, 630, 53-61. [CrossRef]

7. Bosch, A.C.; O’Neill, B.; Sigge, G.O.; Kerwath, S.E.; Hoffman, L.C. Heavy metals in marine fish meat and consumer health: A review. J. Sci. Food Agric. 2016, 96, 32-48. [CrossRef]

8. Lamas, G.A.; Navas-Acien, A.; Mark, D.B.; Lee, K.L. Heavy Metals, Cardiovascular Disease, and the Unexpected Benefits of Chelation Therapy. J. Am. Coll. Cardiol. 2016, 67, 2411-2418. [CrossRef]

9. Ma, Y.; Egodawatta, P.; McGree, J.; Liu, A.; Goonetilleke, A. Human health risk assessment of heavy metals in urban stormwater. Sci. Total Environ. 2016, 557, 764-772. [CrossRef]

10. Hou, D.; O'Connor, D.; Nathanail, P.; Tian, L.; Ma, Y. Integrated GIS and multivariate statistical analysis for regional scale assessment of heavy metal soil contamination: A critical review. Environ. Pollut. 2017, 231, 1188-1200. [CrossRef]

11. Ke, X.; Gui, S.; Huang, H.; Zhang, H.; Wang, C.; Guo, W. Ecological risk assessment and source identification for heavy metals in surface sediment from the Liaohe River protected area, China. Chemosphere 2017, 175, 473-481. [CrossRef] [PubMed]

12. Zinkutè, R.; Taraškevičius, R.; Jankauskaitè, M.; Stankevičius, Ž. Methodological alternatives for calculation of enrichment factors used for assessment of topsoil contamination. J. Soils Sediments 2017, 17, 440-452. [CrossRef]

13. Streets, D.G.; Lu, Z.; Levin, L.; ter Schure, A.F.H.; Sunderland, E.M. Historical releases of mercury to air, land, and water from coal combustion. Sci. Total Environ. 2018, 615, 131-140. [CrossRef]

14. Abraham, J.; Dowling, K.; Florentine, S. Assessment of potentially toxic metal contamination in the soils of a legacy mine site in Central Victoria, Australia. Chemosphere 2018, 192, 122-132. [CrossRef]

15. Shu, X.H.; Zhang, Q.; Lu, G.N.; Yi, X.Y.; Dang, Z. Pollution characteristics and assessment of sulfide tailings from the Dabaoshan Mine, China. Int. Biodeterior. Biodegrad. 2018, 128, 122-128. [CrossRef]

16. Zhou, J.; Liang, J.; Hu, Y.; Zhang, W.; Liu, H.; You, L.; Zhang, W.; Gao, M.; Zhou, J. Exposure risk of local residents to copper near the largest flash copper smelter in China. Sci. Total Environ. 2018, 453-461. [CrossRef]

17. Ma, Y.; Jia, Z.; Li, S. Risk assessment of heavy metals in soil of Tongnan District (Southwest China): Evidence from multiple indices with high-spatial-resolution sampling. Environ. Sci. Pollut. Res. 2017, 24, 20282-20290. [CrossRef]

18. Čujič, M.; Dragovič, S.; Dorđevič, M.; Dragović, R.; Gajić, B. Environmental assessment of heavy metals around the largest coal fired power plant in Serbia. CATENA 2016, 139, 44-52. [CrossRef]

19. ISO. ISO 10381-5:2005 Soil Quality-Sampling-Part 5: Guidance on the Procedure for the Investigation of Urban and Industrial Sites with Regard to Soil Contamination; International Standards Organization: Geneve, Switzerland, 2005.

20. ISO. ISO 10390:2005 Soil Quality, Determination of PH; International Standards Organization: Geneve, Switzerland, 2005.

21. ISO. ISO 11465:1993 Soil Quality_Determination of Dry Matter and Water Content on a Mass Basis—Gravimetric Method; International Standards Organization: Geneve, Switzerland; Beuth: Berlin, Germany, 1993.

22. Reimann, C.; Fabian, K.; Flem, B.; Schilling, J.; Roberts, D.; Englmaier, P. Pb concentrations and isotope ratios of soil $\mathrm{O}$ and $\mathrm{C}$ horizons in Nord-Trøndelag, central Norway: Anthropogenic or natural sources? Appl. Geochem. 2016, 74, 55-66. [CrossRef]

23. MAP 2019. Available online: http://mapy2.ostrava.cz/agenda-zp/ (accessed on 12 January 2019). 
24. Doležalová Weissmannová, H.; Pavlovský, J. Indices of soil contamination by heavy metals - methodology of calculation for pollution assessment (minireview). Environ. Monit. Assess. 2017, 189, 1-25. [CrossRef]

25. Marrugo-Negrete, J.; Pinedo-Hernández, J.; Díez, S. Assessment of heavy metal pollution, spatial distribution and origin in agricultural soils along the Sinú River Basin, Colombia. Environ. Res. 2017, 154, 380-388. [CrossRef]

26. Zhang, P.; Qin, C.; Hong, X.; Kang, G.; Qin, M.; Yang, D.; Pang, B.; Li, Y.; He, J.; Dick, R.P. Risk assessment and source analysis of soil heavy metal pollution from lower reaches of Yellow River irrigation in China. Sci. Total Environ. 2018, 633, 1136-1147. [CrossRef]

27. Hakanson, L. An ecological risk index for aquatic pollution control.a sedimentological approach. Water Res. 1980, 14, 975-1001. [CrossRef]

28. Varol, M. Assessment of heavy metal contamination in sediments of the Tigris River (Turkey) using pollution indices and multivariate statistical techniques. J. Hazard. Mater. 2011, 195, 355-364. [CrossRef]

29. Li, F.; Huang, J.; Zeng, G.; Yuan, X.; Li, X.; Liang, J.; Wang, X.; Tang, X.; Bai, B. Spatial risk assessment and sources identification of heavy metals in surface sediments from the Dongting Lake, Middle China. J. Geochem. Explor. 2013, 132, 75-83. [CrossRef]

30. Shen, F.; Liao, R.; Ali, A.; Mahar, A.; Guo, D.; Li, R.; Xining, S.; Awasthi, M.K.; Wang, Q.; Zhang, Z. Spatial distribution and risk assessment of heavy metals in soil near a $\mathrm{Pb} / \mathrm{Zn}$ smelter in Feng County, China. Ecotoxicol. Environ. Saf. 2017, 139, 254-262. [CrossRef]

31. Adamu, C.I.; Nganje, T.N. Heavy metal contamination of surface soil in relationship to land use patterns: A case study of Benue State, Nigeria. Mater. Sci. Appl. 2010, 1, 127-134. [CrossRef]

32. Kumar, K.R.; Anbazhagan, V. Analysis and assessment of heavy metals in soils around the industrial areas in Mettur, Tamilnadu, India. Env. Monit. Assess. 2018, 190, 519. [CrossRef]

33. Sanjeevani, U.K.P.S.; Indraratne, S.P.; Weerasooriya, R.; Vitharana, U.W.A.; Kumaragamage, D. Identifying the Sources and Contamination Status of Potentially Toxic Trace Elements in Agricultural Soils. Commun. Soil Sci. Plant. Anal. 2017, 48, 865-877. [CrossRef]

34. Müller, G. The heavy metal pollution of the sediments of Neckars and its tributary: A stocktaking. Chem. Ztg. 1981, 105, 157-164.

35. Rudnick, R.L.; Gao, S. Composition of the continental crust. Treatise Geochem. 2003, 3, 659.

36. Yaroshevsky, A.A. Abundances of chemical elements in the Earth's crust. Geochem. Int. 2006, 44, 48. [CrossRef]

37. Kabata-Pendias, A. Trace Elements in Soils and Plants; CRC Press: Boca Raton, FL, USA, 2010; pp. 1-548.

38. Rahman, M.S.; Saha, N.; Molla, A.H. Potential ecological risk assessment of heavy metal contamination in sediment and water body around Dhaka export processing zone, Bangladesh. Environ. Earth Sci. 2014, 71, 2293-2308. [CrossRef]

39. Inengite, A.K.; Abasi, C.; Walter, C. Application of pollution indices for the assessment of heavy metal pollution in flood impacted soil. Int. Res. J. Pure Appl. Chem. 2015, 8, 175-189. [CrossRef]

40. Liang, A.; Wang, Y.; Guo, H.; Bo, L.; Zhang, S.; Bai, Y. Assessment of pollution and identification of sources of heavy metals in the sediments of Changshou Lake in a branch of the Three Gorges Reservoir. Environ. Sci. Pollut. Res. 2015, 22, 16067-16076. [CrossRef]

41. Briki, M.; Zhu, Y.; Gao, Y.; Shao, M.; Ding, H.; Ji, H. Distribution and health risk assessment to heavy metals near smelting and mining areas of Hezhang, China. Environ. Monit. Assess. 2017, 189, 458. [CrossRef]

42. Igwe, O.; Una, C.O.; Abu, E.; Adepehin, E.J. Environmental risk assessment of lead-zinc mining: A case study of Adudu metallogenic province, middle Benue Trough, Nigeria. Environ. Monit. Assess. 2017, 189, 492. [CrossRef]

43. USEPA. Risk Assessment Guidance for Superfund (RAGS). In Volume I: Human Health Evaluation Manual (HHEM)_Part A, Baseline Risk Assessment; Office of Emergency and Remedial Response: Washington, DC, USA, 1989.

44. USEPA (United States Environmental Protection Agency). Exposure Factors Handbook; Office of Research and Development; National Center for Environmental Assessment: Washington, DC, USA, 1997.

45. USEPA (United States Environmental Protection Agency). Risk Assessment Guidance for Superfund: Volume III-Part A, Process for Conducting Probabilistic Risk Assessment; U.S. Environmental Protection Agency: Washington, DC, USA, 2001. 
46. Fryer, M.; Collins, C.D.; Ferrier, H.; Colvile, R.N.; Nieuwenhuijsen, M.J. Human exposure modelling for chemical risk assessment:a review of current approaches and research and policy implications. Environ. Sci. Policy 2006, 9, 261-274. [CrossRef]

47. Hu, W.Y.; Huang, B.; He, Y.; Yusef, K.K. Assessment of potential health risk of heavy metals in soils from a rapidly developing region of China. Hum. Ecol. Risk Assess. 2016, 22, 211-225. [CrossRef]

48. Hu, B.F.; Wang, J.Y.; Jin, B.; Li, Y.; Shi, Z. Assessment of the potential health risks of heavy metals in soils in a coastal industrial region of the Yangtze River Delta. Environ. Sci. Pollut. Res. Int. 2017, 24, 19816-19826. [CrossRef]

49. US Environmental Protection Agency (USEPA). Supplemental Guidance for Developing Soil Screening Levels for Superfund Sites, OSWER 9355; Office of Emergency and Remedial Response: Washington, DC, USA, 2002.

50. Luo, X.S.; Ding, J.; Xu, B.; Wang, Y.J.; Li, H.B.; Yu, S. Incorporating bioaccessibility into human risk assessments of heavy metals in urban park soils. Sci. Total. Environ. 2012, 424, 88-96. [CrossRef]

51. US Environmental Protection Agency (USEPA). Exposure Factors Handbook; (EPA/600/R-09/052F); National Center for Environmental Assessment: Washington, DC, USA, 2011.

52. US Environmental Protection Agency (USEPA). Integrated Risk Information System of the US Environmental Protection Agency; US Environmental Protection Agency (USEPA): Washington, DC, USA, 2012.

53. Diami, S.M.; Kusin, F.M.; Madzin, Z. Potential ecological and human health risks of heavy metals in surface soils associated with iron ore mining in Pahang, Malaysia. Environ. Sci. Pollut. Res. Int. 2016, 23, 21086-21097. [CrossRef]

54. Liu, X.; Song, Q.; Tang, Y.; Li, W.; Xu, J.; Wu, J.; Wang, F.; Brookes, P.C. Human health risk assessment of heavy metals in soil-vegetable system: A multi-medium analysis. Sci. Tot. Environ. 2013, 463, 530-540. [CrossRef]

55. Wang, G.; Zhang, S.; Xiao, L.; Zhong, Q.; Li, L.; Xu, G.; Deng, O.; Pu, Y. Heavy metals in soils from a typical industrial area in Sichuan, China: Spatial distribution, source identification, and ecological risk assessment. Environ. Sci. Pollut. Res. 2017, 24, 16618-16630. [CrossRef]

56. Tepanosyan, G.; Maghakyan, N.; Sahakyan, L.; Saghatelyan, A. Heavy metals pollution levels and children health risk assessment of Yerevan kindergartens soils. Ecotoxicol. Environ. Saf. 2017, 142, 257-265. [CrossRef]

57. Guan, Q.; Wang, F.; Xu, C.; Pan, N.; Lin, J.; Zhao, R.; Yang, Y.; Luo, H. Source apportionment of heavy metals in agricultural soil based on PMF: A case study in Hexi Corridor, northwest China. Chemosphere 2018, 193, 189-197. [CrossRef]

58. Rapant, S.; Fajčíková, K.; Khun, M.; Cvečková, V. Application of health risk assessment method for geological environment at national and regional scales. Environ. Earth Sci. 2010, 64, 513-521. [CrossRef]

59. Li, F.; Huang, J.; Zeng, G.; Huang, X.; Liu, W.; Wu, H.; Yuan, Y.; He, X.; Lai, M. Spatial distribution and health risk assessment of toxic metals associated with receptor population density in street dust: A case study of Xiandao District, Changsha, Middle China. Environ. Sci. Pollut. Res. Int. 2015, 22, 6732-6742. [CrossRef]

60. Faiz, Y.; Siddique, N.; Tufail, M. Pollution level and health risk assessment of road dust from an expressway. J. Environ. Sci. Health A Tox. Hazard. Subst. Environ. Eng. 2012, 47, 818-829. [CrossRef]

(C) 2019 by the authors. Licensee MDPI, Basel, Switzerland. This article is an open access article distributed under the terms and conditions of the Creative Commons Attribution (CC BY) license (http://creativecommons.org/licenses/by/4.0/). 